\title{
Oxidative stress induces autophagic cell death independent of apoptosis in transformed and cancer cells
}

\author{
Y Chen ${ }^{1}$, E McMillan-Ward ${ }^{1}$, J Kong ${ }^{2}$, SJ Israels ${ }^{1,3}$ and SB Gibson ${ }^{1,4}$
}

Autophagy is a self-digestion process that degrades intracellular structures in response to stresses leading to cell survival. When autophagy is prolonged, this could lead to cell death. Generation of reactive oxygen species (ROS) through oxidative stress causes cell death. The role of autophagy in oxidative stress-induced cell death is unknown. In this study, we report that two ROS-generating agents, hydrogen peroxide $\left(\mathrm{H}_{2} \mathrm{O}_{2}\right)$ and 2-methoxyestradiol (2-ME), induced autophagy in the transformed cell line HEK293 and the cancer cell lines U87 and HeLa. Blocking this autophagy response using inhibitor 3-methyladenine or small interfering RNAs against autophagy genes, beclin-1, atg-5 and atg-7 inhibited $\mathrm{H}_{2} \mathrm{O}_{2}$ or 2-ME-induced cell death. $\mathrm{H}_{2} \mathrm{O}_{2}$ and 2-ME also induced apoptosis but blocking apoptosis using the caspase inhibitor zVAD-fmk (benzyloxycarbonyl-Val-Ala-Asp fluoromethylketone) failed to inhibit autophagy and cell death suggesting that autophagy-induced cell death occurred independent of apoptosis. Blocking ROS production induced by $\mathrm{H}_{2} \mathrm{O}_{2}$ or 2-ME through overexpression of manganesesuperoxide dismutase or using ROS scavenger 4,5-dihydroxy-1,3-benzene disulfonic acid-disodium salt decreased autophagy and cell death. Blocking autophagy did not affect $\mathrm{H}_{2} \mathrm{O}_{2-}$ or 2-ME-induced ROS generation, suggesting that ROS generation occurs upstream of autophagy. In contrast, $\mathrm{H}_{2} \mathrm{O}_{2}$ or 2-ME failed to significantly increase autophagy in mouse astrocytes. Taken together, ROS induced autophagic cell death in transformed and cancer cells but failed to induce autophagic cell death in nontransformed cells.

Cell Death and Differentiation (2008) 15, 171-182; doi:10.1038/sj.cdd.4402233; published online 5 October 2007

Autophagy is a regulated lysosomal pathway involved in the degradation and recycling of cytoplasmic materials. ${ }^{1-5}$ During autophagy, cytoplasmic materials are sequestered into double-membraned vesicles, 'autophagosomes', which then fuse with lysosomes to form autolysosomes, where degradation of cellular structures occurs. Some amino acids and fatty acids are produced from this process, which can be used for protein synthesis or be oxidized by the mitochondrial electron transport chain to produce ATP for cell survival under starvation conditions. ${ }^{1}$ Besides cell survival, autophagy can also lead to cell death. Treatment with chemical agents such as arsenic trioxide ${ }^{6,7}$ or overexpression of tumor suppressor proteins such as the short mitochondrial form of $\mathrm{p} 19^{\mathrm{ARF}} 8$ initiate an autophagic response that leads to cell death. A conditionally replicating adenovirus was able to induce autophagic cell death in malignant glioma cancer cells. ${ }^{9}$ In addition, autophagic cell death has been achieved where apoptosis is blocked by caspase inhibitors or in cells lacking Bax and Bak expression. ${ }^{10,11}$ The mechanism of regulating autophagy-induced cell death remains unclear.
Many cellular stresses can cause induction of autophagy such as endoplasmic reticulum stress or mitochondrial dysfunction. ${ }^{3}$ Oxidative stress has been shown to induce autophagy under starvation and ischemia/reperfusion conditions. ${ }^{12,13}$ Under oxidative stress, reactive oxygen species (ROS) including free radicals such as superoxide $\left(\mathrm{O}_{2}^{{ }^{-}}\right)$, hydroxyl radical $\left(\mathrm{HO}^{\circ}\right)$ and hydrogen peroxide $\left(\mathrm{H}_{2} \mathrm{O}_{2}\right)$ are generated at high levels inducing cellular damage and cell death. ${ }^{14}$ This cell death often involves induction of apoptosis through caspase activation. Blockage of caspase activation causes degradation of catalase and increased ROS generation leading to cell death. The degradation of catalase is mediated by autophagy indicating a role for autophagy in caspase-independent cell death. ${ }^{15}$ Furthermore, ROS contribute to caspase-independent cell death in macrophages. ${ }^{11}$ Under starvation conditions, ROS production is increased and is required for induction of autophagy. ${ }^{13}$ The ability of oxidative stress to induce autophagy-induced cell death is unknown.

Cancer cells produce higher levels of ROS than normal cells due to increased metabolic stress and proliferative

\footnotetext{
${ }^{1}$ Manitoba Institute of Cell Biology, 675 McDermot Ave, Winnipeg, Manitoba, Canada; ${ }^{2}$ Department of Human Anatomy and Cell Science, Faculty of Medicine, University of Manitoba, Winnipeg, Manitoba, Canada; ${ }^{3}$ CancerCare Manitoba, 675 McDermot Ave, Winnipeg, Manitoba, Canada and ${ }^{4}$ Biochemistry and Medical Genetics, Faculty of Medicine, University of Manitoba, Winnipeg, Manitoba, Canada

Corresponding author: SB Gibson, Manitoba Institute of Cell Biology, 675 McDermot Ave, Winnipeg, Manitoba, Canada R3E 0V9. Tel: + 204 787 2051;

Fax: + 204787 2190; E-mail: gibsonsb@cc.umanitoba.ca

Keywords: reactive oxygen species; 2-methoxyestradiol; autophagic cell death; apoptosis

Abbreviations: AO, acridine orange; AVOs, acidic vesicular organelles; $\mathrm{EB}$, ethidium bromide; GFP, green fluorescent protein; $\mathrm{H}_{2} \mathrm{O}_{2}$, hydrogen peroxide; $\mathrm{HE}$, dihydroethidium; LC3, microtubule-associated protein light chain 3; ROS, reactive oxygen species; siRNA, small interfering RNA; SOD2, manganese-superoxide dismutase; tiron, 4,5-dihydroxy-1,3-benzene disulfonic acid-disodium salt; zVAD (zVAD fmk), benzyloxycarbonyl-Val-Ala-Asp fluoromethylketone; 2-ME, 2methoxyestradiol; 3-MA, 3-methyladenine

Received 05.4.07; revised 20.8.07; accepted 28.8.07; Edited by E Baehrecke; published online 05.10.07
} 
capacity. ${ }^{16-18}$ ROS are known to be involved in the initiation and progression of cancers, DNA damage, genetic instability, cellular injury, alterations in drug sensitivity and cell death. ${ }^{14,17,18}$ To maintain ROS at tolerable levels, cancer cells have an antioxidant system where antioxidant enzymes such as manganese-superoxide dismutase (SOD), catalase and glutathione peroxidase eliminate ROS. ${ }^{14}$ Thus cancer cells may be more sensitive to oxidative stress due to high endogenous ROS levels and may provide a selective mechanism to induce cell death.

$\mathrm{H}_{2} \mathrm{O}_{2}$ and 2-methoxyestradiol (2-ME, inhibitor of SOD) were reported to induce oxidative stress and cell death in cancer cells. ${ }^{19,20}$ In this study, we demonstrated for the first time that $\mathrm{H}_{2} \mathrm{O}_{2}$ and 2-ME treatment induced autophagy contributing to cell death in the transformed cell line HEK293 and the cancer cell lines U87 and HeLa but not in nontransformed mouse astrocytes. Inhibition of autophagy decreased $\mathrm{H}_{2} \mathrm{O}_{2}$ or 2-MEinduced cell death without affecting the apoptotic response. In contrast, under the treatment of cells by $\mathrm{H}_{2} \mathrm{O}_{2}$ or 2-ME, inhibition of apoptosis appears to slightly increase autophagyinduced cell death although the levels of total cell death remained unchanged. This indicates that oxidative stress could selectively induce autophagic cell death in transformed cells providing a novel strategy for cancer treatment.

\section{Results}

$\mathrm{H}_{2} \mathrm{O}_{2}$ and 2-ME induce autophagy. Autophagy is characterized by the formation of double-membraned autophagosomes that fuse with lysosomes to form autolysosomes. Lysosomes and autolysosomes are forms of acidic vesicular organelles (AVOs). Autophagosome formation also involves the induction of beclin-1 expression, and the location of microtubule-associated protein light chain 3 (LC3) in autophagosomes. ${ }^{1-5}$ In this study, the number of autophagosomes in the cells was detected by measuring (i) formation of AVOs by flow cytometry, (ii) electron microscopy (EM) of autophagosomes, (iii) formation of green fluorescent protein (GFP)-LC3 vacuoles by transfection and fluorescent microscopy, (iv) conversion of the cytoplasmic form of LC3 (LC3-I, $18 \mathrm{kDa}$ ) to the preautophagosomal and autophagosomal membrane-bound form of LC3 (LC3-II, $16 \mathrm{kDa}$ ) by western blot and (v) expression of beclin-1 by Western blot. HEK293 and U87 cells were incubated with $1.0 \mathrm{mM} \mathrm{H}_{2} \mathrm{O}_{2}$ or $0.1 \mathrm{mM} 2-\mathrm{ME}$ for 24,48 and $72 \mathrm{~h} . \mathrm{H}_{2} \mathrm{O}_{2}$ and 2-ME induced AVOs formation in HEK293 and U87 cells (Figure 1ai and Supplementary Figure S1). As a positive control, AVOs formation was also measured after HEK293 cells were starved of glucose and sodium pyruvate for 3 days (Supplementary Figure S2). In addition, the autophagy inhibitor 3-methyladenine (3-MA) significantly reduced AVOs formation induced by $\mathrm{H}_{2} \mathrm{O}_{2}$ and 2-ME, whereas the caspase inhibitor z-VAD-fmk (z-VAD) failed to change AVO formation in HEK293 cells (Figure 1aii). 3-MA also significantly reduced AVO formation induced by starvation (Supplementary Figure S2). Using electron microscopy, we also identified double-membrane autophagosomes (arrows) in HEK293 cells after treatment with $\mathrm{H}_{2} \mathrm{O}_{2}$ for $48 \mathrm{~h}$ that was not present in untreated cells (Figure 1b). Since LC3 is a specific marker for autophagosome formation, ${ }^{3}$ GFP-LC3 cDNA in a mammalian expression vector was transfected into HEK293 and U87 cells, and cells with GFP-LC3 vacuoles (dots) were counted using a fluorescent microscope. In agreement with the results of AVOs formation, images of HEK293 and U87 cells in Figure 1ci clearly indicate that GFP-LC3 is localized in vacuoles (dots) after treatment with $\mathrm{H}_{2} \mathrm{O}_{2}$ and 2-ME for $48 \mathrm{~h}$. When quantified, $\mathrm{H}_{2} \mathrm{O}_{2}$ and 2-ME induced significant formation of GFP-LC3 vacuoles in HEK293 (Figure 1cii) and U87 cells (Supplementary Figure S3). 3-MA also reduced formation of GFP-LC3 vacuoles induced by $\mathrm{H}_{2} \mathrm{O}_{2}$ and 2-ME in both HEK293 (Figure 1cii) and U87 cells (Supplementary Figure S3). In contrast, the caspase inhibitor z-VAD seemed to increase GFP-LC3 vacuoles in HEK293 cells (Figure 1cii). As a control, starvation increased GFP-LC3 vacuoles that were reduced by 3-MA treatment (Supplementary Figure S2). Another specific marker for autophagosomes is the conversion of LC3-I to LC3-II. In HEK293 and U87 cells, both $\mathrm{H}_{2} \mathrm{O}_{2}$ and 2-ME induced significantly higher amount of LC3-II expression compared to control after $24 \mathrm{~h}$ of treatment (Figure 1d). Beclin-1 expression is involved in the formation of preautophagosomal structures. Similar to LC3-II, the expression of beclin-1 was increased following $6 \mathrm{~h}$ of $\mathrm{H}_{2} \mathrm{O}_{2}$ or 2-ME treatment in HEK293 and U87 cells (Figure 1d). Taken together, $\mathrm{H}_{2} \mathrm{O}_{2}$ and 2-ME induced an autophagic response.

$\mathrm{H}_{2} \mathrm{O}_{2}$ or 2-ME-induced cell death involves autophagy. $\mathrm{H}_{2} \mathrm{O}_{2}$ and 2-ME have previously been shown to induce cell death. ${ }^{19,21,22}$ To confirm that $\mathrm{H}_{2} \mathrm{O}_{2}$ and 2-ME induce cell death in HEK293 and U87 cells, cells were treated with $\mathrm{H}_{2} \mathrm{O}_{2}$ or 2-ME over a $72 \mathrm{~h}$ time course and cell death was measured by membrane permeability. Both $\mathrm{H}_{2} \mathrm{O}_{2}$ and 2-ME induced cell death in HEK293 and U87 cells (Figure 2a). Cells were treated with $\mathrm{H}_{2} \mathrm{O}_{2}$ and 2-ME in the presence or absence of 3-MA. In HEK293 and U87 cells, $\mathrm{H}_{2} \mathrm{O}_{2}$ - and 2-ME-induced cell death was inhibited by the addition of 3-MA (Figure 2b).

Since autophagy requires the expression of autophagy genes such as beclin-1, atg-5 and atg-7 to form autophagosomes,${ }^{1-5}$ we hypothesized that the suppression of beclin-1, ATG-5 and ATG-7 expression will decrease $\mathrm{H}_{2} \mathrm{O}_{2}$ - or 2-MEinduced cell death. In HEK293 cells, the expression of beclin1, ATG-5 and ATG-7 was reduced following transfection of small interfering RNA (siRNA) against beclin-1, atg-5 and atg-7 (Figure 2ci). The level of $\mathrm{H}_{2} \mathrm{O}_{2}$ - and 2-ME-induced autophagosomes (formation of AVOs and GFP-LC3 vacuoles) was decreased by beclin-1, atg-5 and atg-7 siRNAs, respectively (Figures 2cii and iii). The level of $\mathrm{H}_{2} \mathrm{O}_{2}$ - and 2ME-induced cell death was also decreased by beclin-1, atg-5 and atg-7 siRNAs (Figures 2civ). Similar results were obtained using the cancer cell line HeLa and U87 cells (data not shown and Supplementary Figure S4). Taken together, this indicates that $\mathrm{H}_{2} \mathrm{O}_{2}$ and 2-ME induce autophagic cell death.

Autophagy-induced cell death occurs independent of apoptosis following oxidative stress. Both $\mathrm{H}_{2} \mathrm{O}_{2}$ and 2-ME have previously been reported to induce apoptosis. ${ }^{21,22}$

We have determined that in HEK293 cells, $\mathrm{H}_{2} \mathrm{O}_{2}$ and 2-ME induced apoptosis (formation of sub-G1 peaks), whereas in 


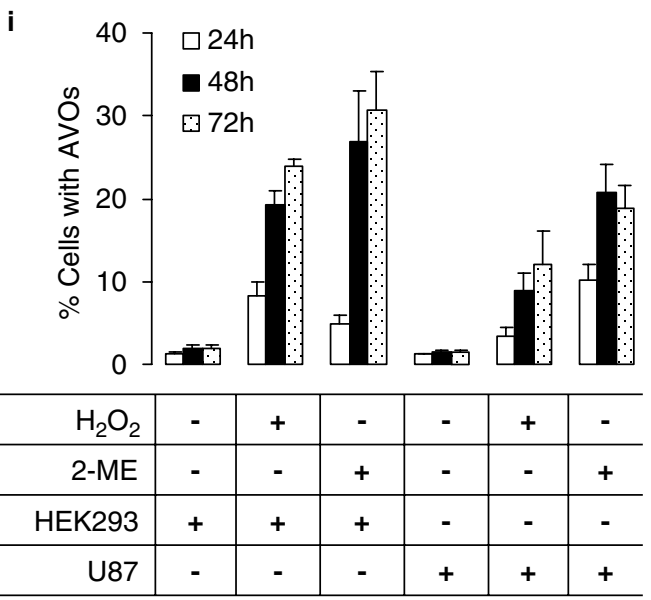

b

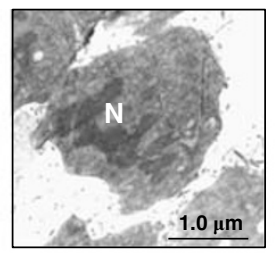

Control

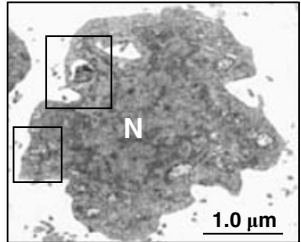

$\mathrm{H}_{2} \mathrm{O}_{2}$

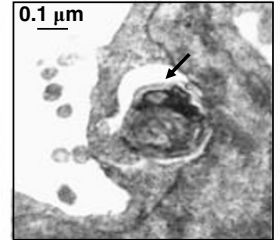

$\mathrm{H}_{2} \mathrm{O}_{2}$ (enlarged) d

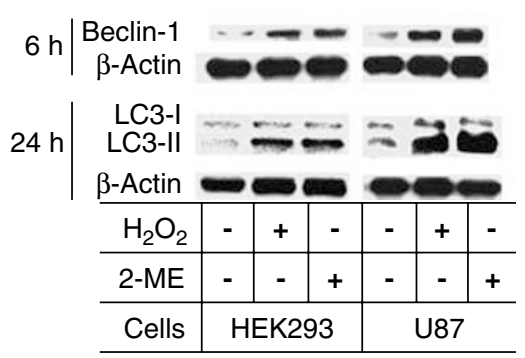

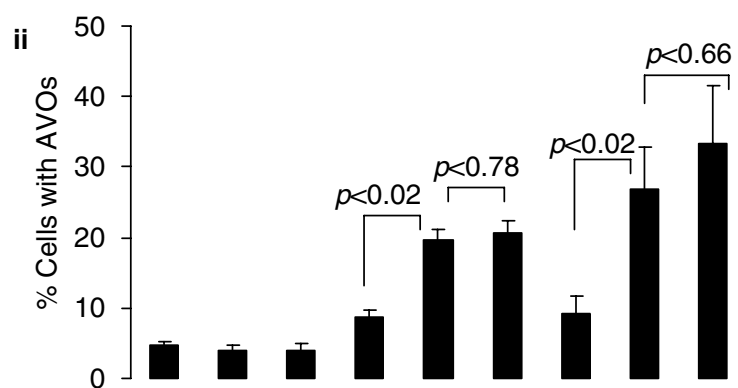

\begin{tabular}{r|c|c|c|c|c|c|c|c|c}
\hline $\mathrm{H}_{2} \mathrm{O}_{2}$ & - & - & - & + & + & + & - & - & - \\
\hline 2-ME & - & - & - & - & - & - & + & + & + \\
\hline 3-MA & - & + & - & + & - & - & + & - & - \\
\hline zVAD & - & - & + & - & - & + & - & - & + \\
\hline
\end{tabular}

HEK293 cells

C i
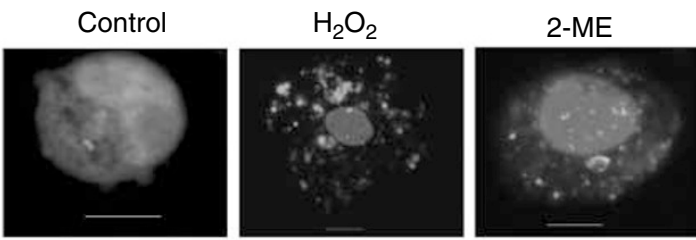

U87
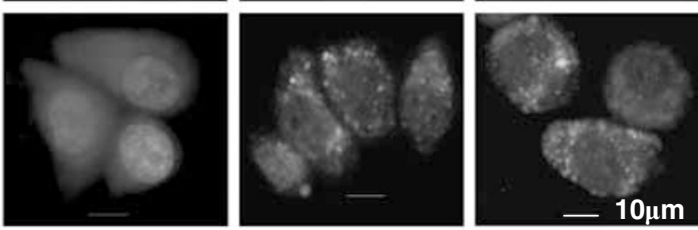

ii

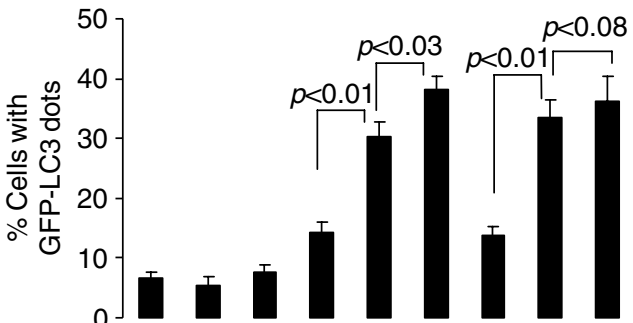

\begin{tabular}{r|c|c|c|c|c|c|c|c|c}
\hline $\mathrm{H}_{2} \mathrm{O}_{2}$ & - & - & - & + & + & + & - & - & - \\
\hline $2-\mathrm{ME}$ & - & - & - & - & - & - & + & + & + \\
\hline $3-\mathrm{MA}$ & - & + & - & + & - & - & + & - & - \\
\hline $\mathrm{zVAD}$ & - & - & + & - & - & + & - & - & + \\
\hline \multicolumn{1}{c}{$\mathrm{HEK} 293$ cells }
\end{tabular}

Figure $1 \mathrm{H}_{2} \mathrm{O}_{2}$ and 2-ME induced autophagy in $\mathrm{HEK} 293$ and $\mathrm{U} 87$ cells. Cells were treated with $\mathrm{H}_{2} \mathrm{O}_{2}(1.0 \mathrm{mM})$ or 2-ME $(0.1 \mathrm{mM})$ for the times indicated. (a) Formation of AVOs (acidic vesicular organelles) was determined in HEK293 and U87 cells as described in Materials and Methods section. AVO formation was determined over a (i) 72 -h time course and (ii) the affect of autophagy inhibitor 3-MA $(2.0 \mathrm{mM})$ and caspase inhibitor ZVAD $(0.1 \mathrm{mM})$ on AVO formation was determined. (b) Electron microscopy pictures were taken of HEK293 cells untreated (control) or treated with $\mathrm{H}_{2} \mathrm{O}_{2}$ for $48 \mathrm{~h}$. Double membrane vacuole are denoted by arrow and nucleus is denoted by N. (c) Formation of GFP-LC3 vacuoles (dots) was determined after HEK293 and U87 cells were transfected with GFP or GFP-LC3 cDNA and treated with $\mathrm{H}_{2} \mathrm{O}_{2}$ or 2-ME for $48 \mathrm{~h}$. (i) Examples of the fluorescent microscopic pictures showing GFP-LC3 vacuoles (dots) in HEK293 and U87 cells. (ii) Percentage of cells with GFP-LC3 vacuoles (dots) and effects of 3-MA and ZVAD were determined. Vacuoles (dots) failed to be observed in GFP alone cells treated with or without $\mathrm{H}_{2} \mathrm{O}_{2}$ and 2-ME (data not shown). (d) Beclin-1 expression and conversion of LC3-I to LC3-II were determined by western blotting after HEK293 and U87 cells were treated with $\mathrm{H}_{2} \mathrm{O}_{2}$ and 2-ME for 6 and $24 \mathrm{~h}$, respectively. $\beta$-Actin was western blotted as a loading control. 3-MA and ZVAD were preincubated with cells for $1 \mathrm{~h}$ before the addition of $\mathrm{H}_{2} \mathrm{O}_{2}$ or 2-ME. Standard error represents three independent experiments. $P$-value represents significant difference between conditions where $P<0.05$

U87 cells only 2-ME induced apoptosis over a $72 \mathrm{~h}$ time course (Figure 3a, Supplementary Figure S5). Since apoptosis occurs in these cells, we then determined whether autophagy contributes to $\mathrm{H}_{2} \mathrm{O}_{2}$ - or 2-ME-induced apoptosis.
First, the inhibition of autophagy on apoptosis was investigated. Figure $3 b$ shows that 3-MA had no effect on $\mathrm{H}_{2} \mathrm{O}_{2}$ - or 2-ME-induced apoptosis in HEK293 cells. In U87 cells, 2-ME-induced apoptosis also failed to be changed by addition 
a

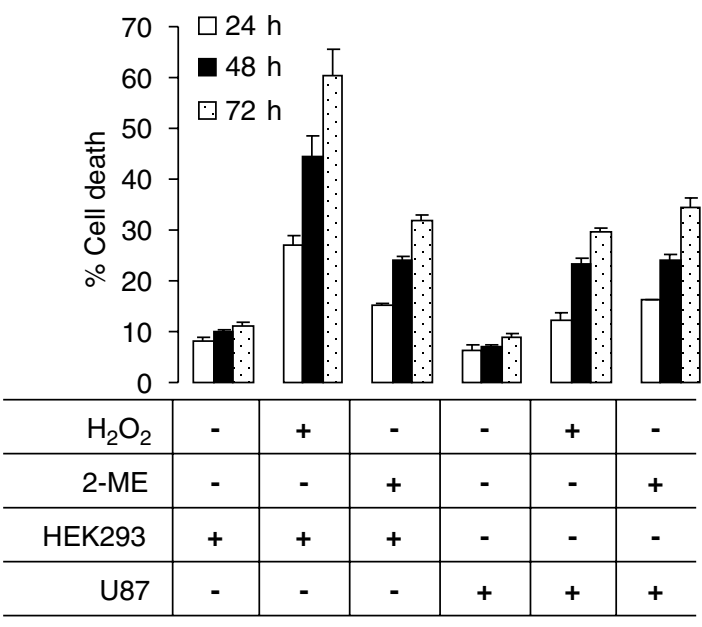

b

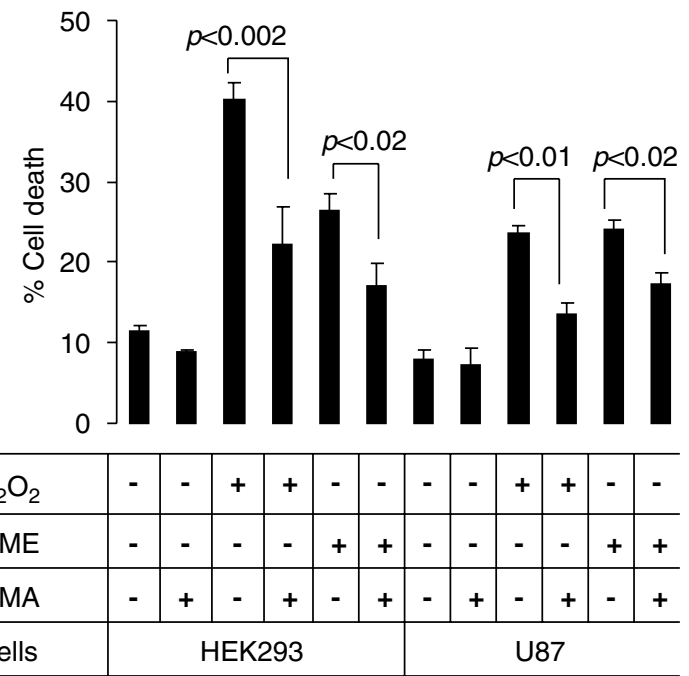

c i

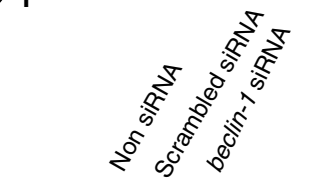

Beclin-1 $=$ ATG-5

$\beta$-Actin $=\infty$-Actin
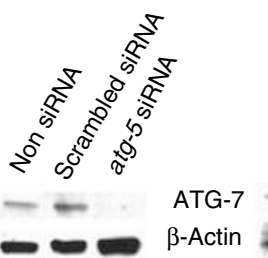

HEK293 cells

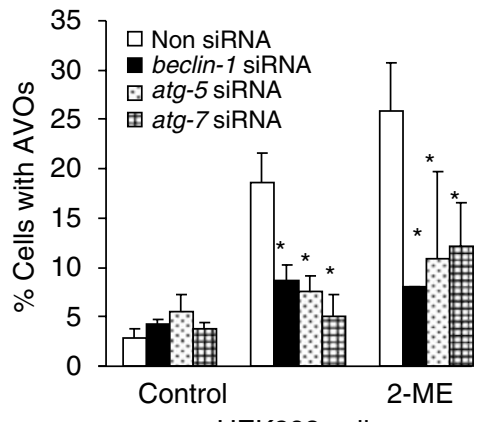

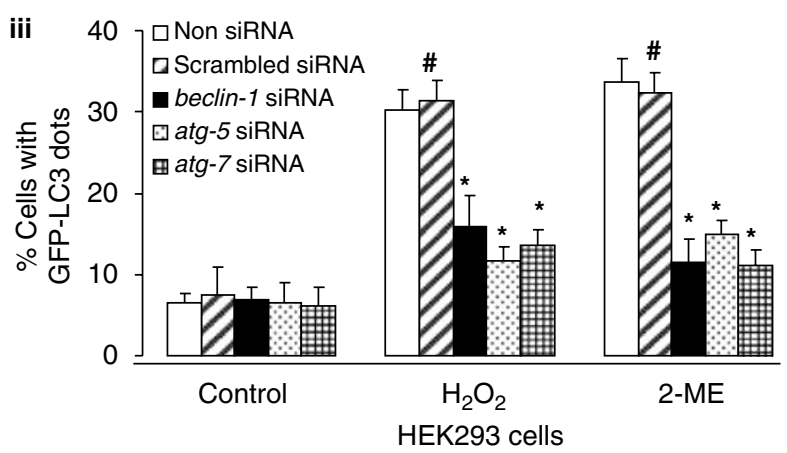

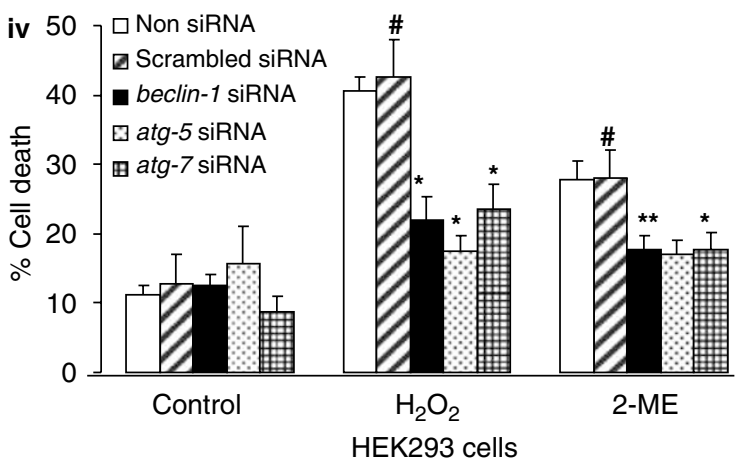

Figure $2 \mathrm{H}_{2} \mathrm{O}_{2}$ and 2-ME induced autophagic cell death in HEK293 and U87 cells. HEK293 and U87 cells were treated with $\mathrm{H}_{2} \mathrm{O}_{2}(1.0 \mathrm{mM})$, 2-ME (0.1 mM) and/or 3-MA $(2.0 \mathrm{mM})$. (a) Cell death was measured by membrane permeablization as described in Materials and Methods section in a 72-h time course. (b) The effect of 3-MA on cell death was determined after HEK293 and U87 cells were treated for $48 \mathrm{~h}$. 3-MA was preincubated with cells for $1 \mathrm{~h}$ before the addition of $\mathrm{H}_{2} \mathrm{O}_{2}$ or 2-ME. (c) Expression of autophagy genes beclin- 1 or atg-5 or atg-7 was silenced by siRNAs in HEK293 cells, and autophagy and cell death were determined after treatment with $\mathrm{H}_{2} \mathrm{O}_{2}$ and 2-ME for $48 \mathrm{~h}$. (i) Beclin-1, ATG-5 and ATG-7 expression was determined by western blotting of HEK293 cells transfected with siRNA as described in Materials and Methods section. $\beta$-Actin was western blotted for equal loading. (ii) AVOs formation and (iii) formation of GFP-LC3 vacuoles (dots) was determined as described in Materials and Method section. (iv) Cell death was determined by membrane permeablization as described in Materials and Method section. *Represents $P<0.05$ compared to 'Non siRNA' condition. \#Represents $P>0.05$ compared to 'Non siRNA' condition. Standard error represents three independent experiments

of 3-MA (data not shown). Furthermore, $\mathrm{H}_{2} \mathrm{O}_{2}$ - and 2-MEinduced apoptosis was not affected by beclin-1, atg-5 and atg-7 siRNAs transfection in HEK293 cells (Figure 3c) or in HeLa and U87 cells (data not shown, Supplementary Figure S4E). Second, the inhibition of apoptosis on autophagy and cell death was investigated. In HEK293 cells, apoptosis (formation of sub-G1 peaks) induced by $\mathrm{H}_{2} \mathrm{O}_{2}$ and 2-ME was inhibited following treatment with zVAD (Figure $3 b$ ).
However, zVAD slightly increased autophagosomes induced by $\mathrm{H}_{2} \mathrm{O}_{2}$ (Figure 1cii). Finally, $z-V A D$ failed to inhibit $\mathrm{H}_{2} \mathrm{O}_{2}-$ or 2-ME-induced cell death (Figure $3 \mathrm{~d}$ ). This suggests that part of apoptotic cell death may have shifted to autophagic cell death after apoptosis was inhibited by zVAD. Taken together, these results indicate that $\mathrm{H}_{2} \mathrm{O}_{2}$ - or 2-ME-induced autophagic cell death is independent of apoptosis. 
a
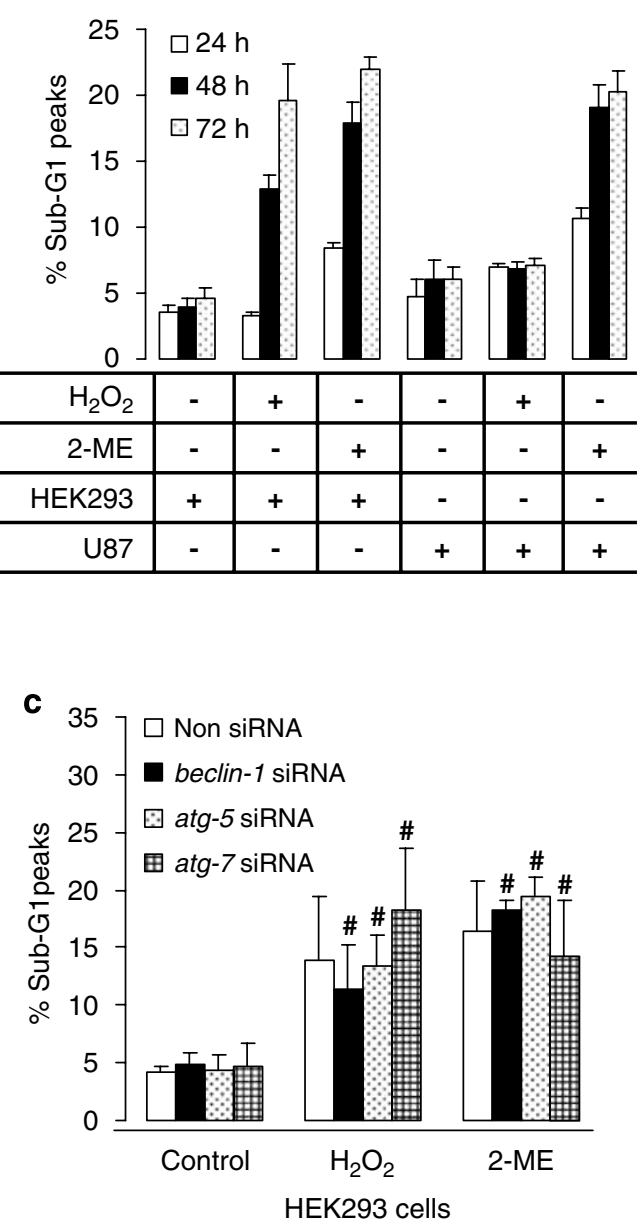

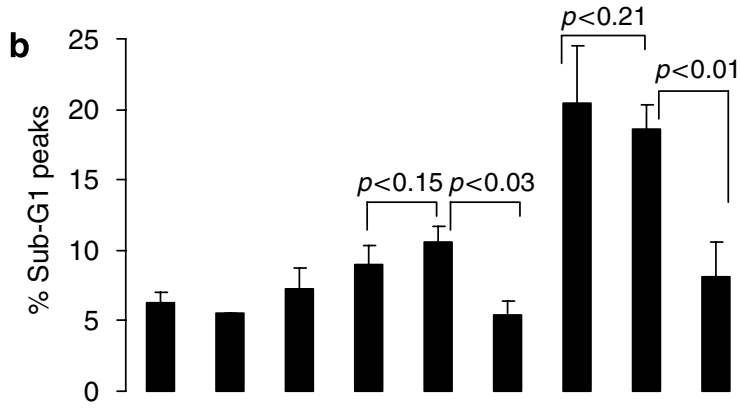

\begin{tabular}{r|c|c|c|c|c|c|c|c|c}
\hline $\mathrm{H}_{2} \mathrm{O}_{2}$ & - & - & - & + & + & + & - & - & - \\
\hline $2-\mathrm{ME}$ & - & - & - & - & - & - & + & + & + \\
\hline $3-\mathrm{MA}$ & - & + & - & + & - & - & + & - & - \\
\hline $\mathrm{ZVAD}$ & - & - & + & - & - & + & - & - & + \\
\hline \multicolumn{8}{c}{ HEK293 cells }
\end{tabular}

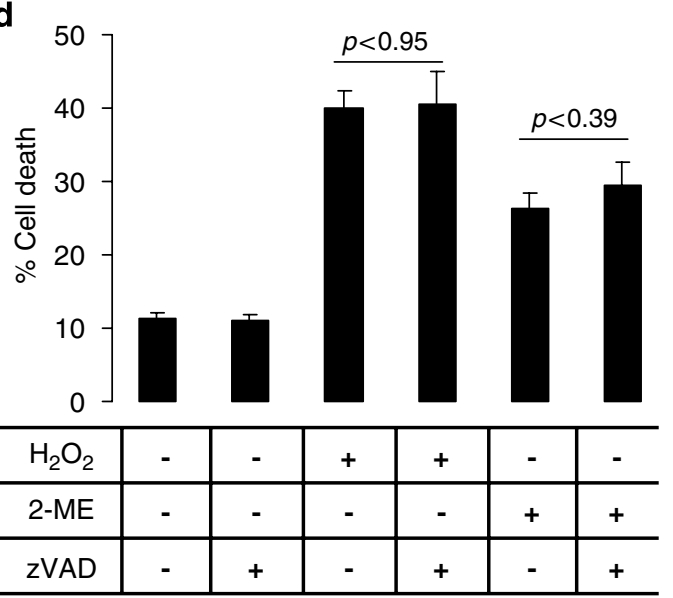

HEK293 cells

Figure 3 Autophagic cell death induced by $\mathrm{H}_{2} \mathrm{O}_{2}$ or 2-ME is independent of apoptosis. HEK293 and U87 cells were treated with $\mathrm{H}_{2} \mathrm{O}_{2}(1.0 \mathrm{mM}), 2-\mathrm{ME}(0.1 \mathrm{mM}), \mathrm{zVAD}$ $(0.1 \mathrm{mM})$ and/or 3-MA (2.0 mM). 3-MA and ZVAD were preincubated with cells for $1 \mathrm{~h}$ before the addition of $\mathrm{H}_{2} \mathrm{O}_{2}$ or 2-ME. (a) $\mathrm{H}_{2} \mathrm{O}_{2}$ - and 2-ME-induced apoptosis (formation of sub-G1 peaks) was determined in HEK293 and U87 cells over a 72-h time course. (b) The amount of apoptosis was determined in HEK293 cells following treatment with the autophagy inhibitor 3-MA or the caspase inhibitor zVAD alone or in combination with $\mathrm{H}_{2} \mathrm{O}_{2}$ or 2-ME for $48 \mathrm{~h}$. (c) Silencing of Beclin-1, ATG-5 and ATG-7 expression by siRNAs was performed on HEK293 cells as described in Materials and Methods section. The amount of apoptosis was determined following $\mathrm{H}_{2} \mathrm{O}_{2}$ or 2-ME treatment for $48 \mathrm{~h}$. \#Represents $P>0.05$ compared to 'Non siRNA' condition. (d) Effect of ZVAD on cell death after HEK293 cells were treated with $\mathrm{H}_{2} \mathrm{O}_{2}$ and 2-ME for $48 \mathrm{~h}$. Standard error represents three independent experiments. $P$-value represents significant difference between conditions where $P<0.05$

ROS mediate $\mathrm{H}_{2} \mathrm{O}_{2}$ - or 2-ME-induced autophagic cell death. $\mathrm{H}_{2} \mathrm{O}_{2}$ and 2-ME have been reported to induce $\mathrm{ROS}$ generation and cell death. ${ }^{19,20}$ It is known that ROS generation is associated with apoptosis. ${ }^{20,23} \mathrm{We}$ hypothesize that ROS are the trigger for autophagy and autophagic cell death. In HEK293 cells, $\mathrm{H}_{2} \mathrm{O}_{2}$ and 2-ME induced similar levels of ROS generation, whereas in U87 cells they induced lower levels of ROS generation over a $72 \mathrm{~h}$ time course (Supplementary data, Figure S6). As expected, the ROS scavenger tiron (4,5-dihydroxy-1,3-benzene disulfonic acid-disodium salt) at $1 \mathrm{mM}$ decreased the level of $\mathrm{H}_{2} \mathrm{O}_{2}$ - and 2-ME-induced ROS generation in HEK293 cells (Figure 4a). Tiron also significantly blocked $\mathrm{H}_{2} \mathrm{O}_{2}$-or 2-ME-induced autophagosome accumulation. The formation of AVOs and GFP-LC3 vacuoles induced by $\mathrm{H}_{2} \mathrm{O}_{2}$ and 2-ME was decreased following addition of tiron (Figure 4bi). Expression of beclin-1 and conversion of LC3-I to LC3-II induced by $\mathrm{H}_{2} \mathrm{O}_{2}$ or 2-ME were also suppressed by the addition of tiron (Figure 4bii). The addition of tiron also reduced the levels of cell death induced by $\mathrm{H}_{2} \mathrm{O}_{2}$ and 2-ME in HEK293 cells (Figure 4c). Interestingly, $\mathrm{H}_{2} \mathrm{O}_{2}$ - or 2-ME-induced apoptosis (formation of sub-G1 peaks) was not affected by the addition of tiron (Figure 4d). This suggests that ROS are involved in the induction of autophagosomes and autophagic cell death induced by $\mathrm{H}_{2} \mathrm{O}_{2}$ or 2-ME.

Another way to reduce ROS damage is to enhance the ability of the antioxidant system in cells. In cells, antioxidant enzymes such as SOD, catalase and glutathione peroxidase can eliminate ROS. ${ }^{14}$ In HeLa cells, stably overexpressing SOD2 (the SOD locates in the matrix side of mitochondria) dramatically decreased the levels of ROS generation induced by $\mathrm{H}_{2} \mathrm{O}_{2}$ and 2-ME (Figure 5a). Formation of AVOs and GFP-LC3 vacuole following $\mathrm{H}_{2} \mathrm{O}_{2}$ and 2-ME treatment were 


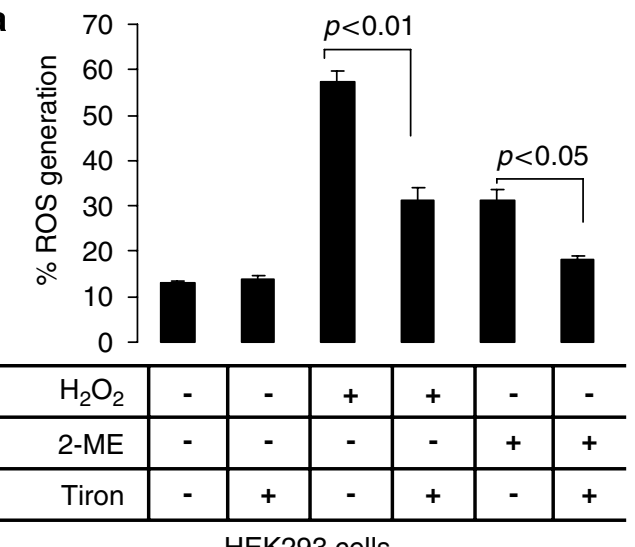

c

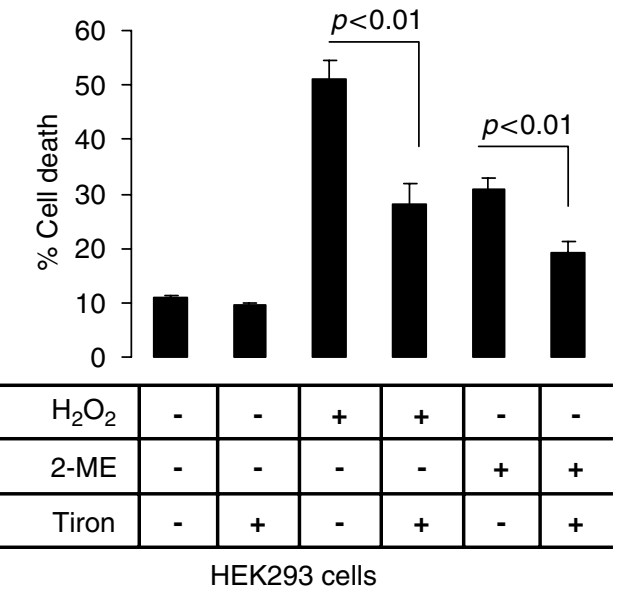

b i

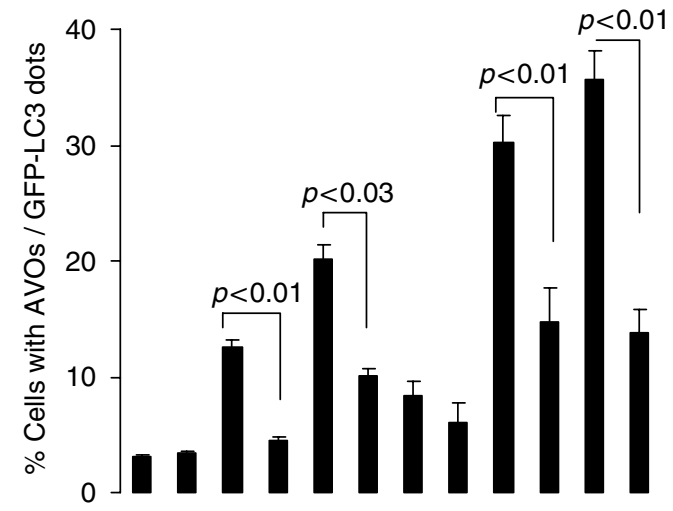

\begin{tabular}{c|c|c|c|c|c|c|c|c|c|c|c|c}
\hline $\mathrm{H}_{2} \mathrm{O}_{2}$ & - & - & + & + & - & - & - & - & + & + & - & - \\
\hline $2-\mathrm{ME}$ & - & - & - & - & + & + & - & - & - & - & + & + \\
\hline Tiron & - & + & - & + & - & + & - & + & - & + & - & + \\
\hline Autophagy & \multicolumn{3}{|c}{ AVOs } & \multicolumn{6}{c}{ GFP-LC3 dots } \\
\hline
\end{tabular}

HEK293 cells

ii

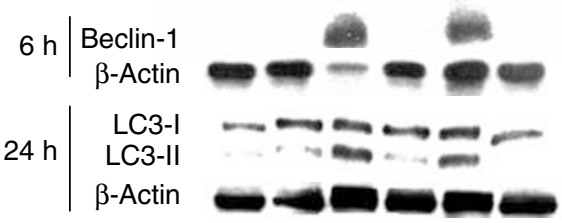

\begin{tabular}{c|c|c|c|c|c|c}
\hline $\mathrm{H}_{2} \mathrm{O}_{2}$ & - & - & + & + & - & - \\
\hline $2-\mathrm{ME}$ & - & - & - & - & + & + \\
\hline Tiron & - & + & - & + & - & + \\
\hline
\end{tabular}

HEK293 cells
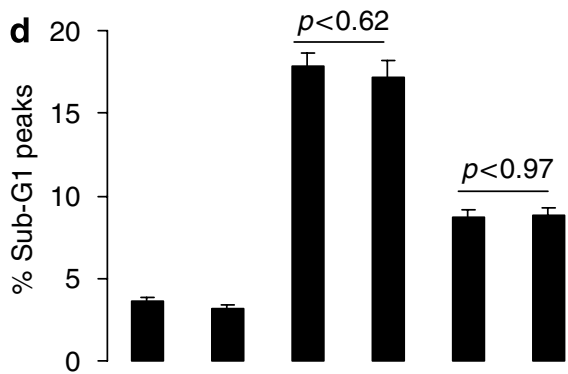

\begin{tabular}{c|c|c|c|c|c|c}
\hline $\mathrm{H}_{2} \mathrm{O}_{2}$ & - & - & + & + & - & - \\
\hline $2-\mathrm{ME}$ & - & - & - & - & + & + \\
\hline Tiron & - & + & - & + & - & + \\
\hline
\end{tabular}

HEK293 cells

Figure 4 Tiron decreases autophagic cell death induced by $\mathrm{H}_{2} \mathrm{O}_{2}$ and 2-ME. HEK293 cells were treated with $\mathrm{H}_{2} \mathrm{O}_{2}(1.0 \mathrm{mM})$ and 2-ME $(0.1 \mathrm{mM})$ with and without tiron $(1.0 \mathrm{mM})$ for $48 \mathrm{~h}$. When included, tiron was preincubated with cells for $1 \mathrm{~h}$. (a) Reactive oxygen species (ROS) was determined as described in Materials and Method section. (b) (i) Formation of AVOs and GFP-LC3 vacuoles (dots) were determined as described above. (ii) Expression of beclin-1 and conversion of LC3-I to LC3-II were determined by western blotting. $\beta$-Actin was western blotted as a loading control. (c) Cell death was determined by membrane permeablization. (d) Apoptosis was determined by formation of sub G: peak as described in Materials and Methods section. Standard error represents three independent experiments. $P$-value represents significant difference between conditions where $P<0.05$

decreased by overexpression of SOD2, to the levels similar to control (Figure 5bi). Expression of beclin-1 and conversion of LC3-I to LC3-II induced by $\mathrm{H}_{2} \mathrm{O}_{2}$ and 2-ME were also greatly suppressed by overexpression of SOD2 (Figure 5bii). Lastly, overexpression of SOD2 decreased the levels of $\mathrm{H}_{2} \mathrm{O}_{2}$ - and
2-ME-induced cell death (Figure $5 \mathrm{c}$ ). When 3-MA was added, the levels of $\mathrm{H}_{2} \mathrm{O}_{2}$ - and 2-ME-induced cell death were decreased in the wild-type cells, but in the SOD2-overexpressing cells, the levels of cell death were not affected (Figure 5c). Taken together, overexpression of SOD2 in HeLa 
a

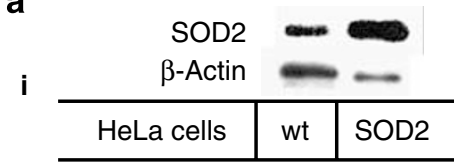

ii

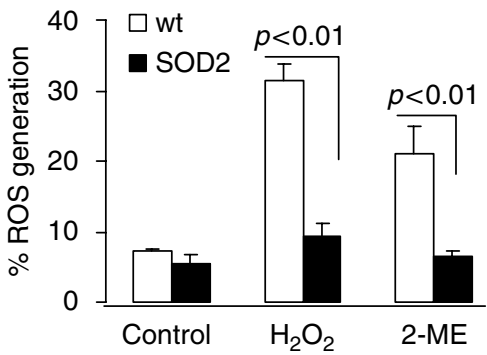

HeLa cells

c

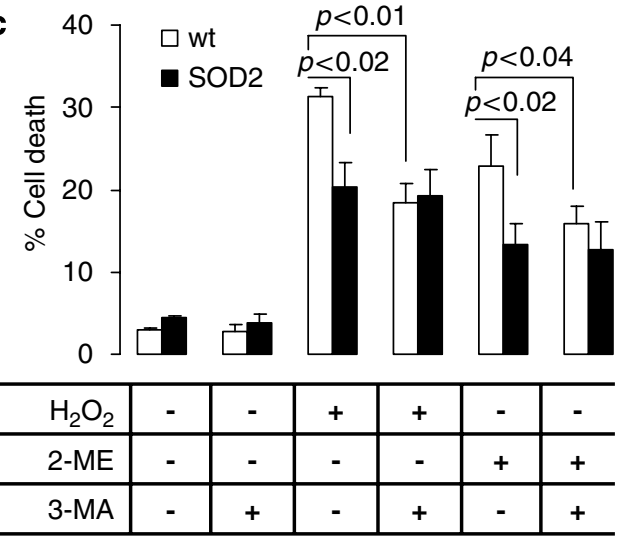

HeLa cells b

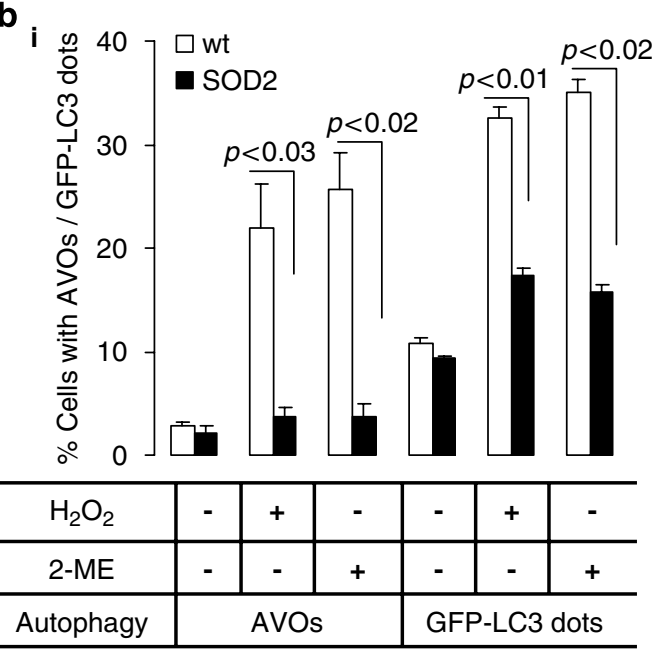

HeLa cells

ii

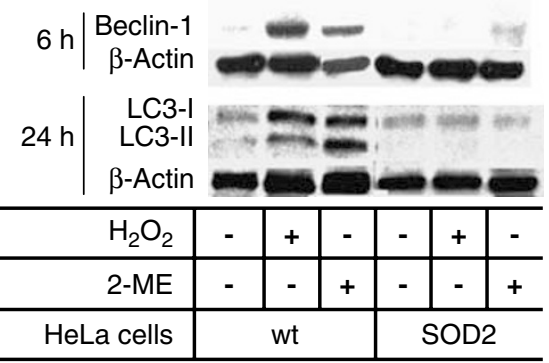

Figure 5 Overexpression of SOD2 decreases autophagic cell death induced by $\mathrm{H}_{2} \mathrm{O}_{2}$ and 2-ME. Wild-type (wt) and SOD2-overexpressed (SOD2) HeLa cells were treated with $\mathrm{H}_{2} \mathrm{O}_{2}(1.0 \mathrm{mM})$ and 2-ME $(0.1 \mathrm{mM})$ with or without 3-MA $(2.0 \mathrm{mM})$ for $24 \mathrm{~h}$. 3-MA was preincubated with cells for $1 \mathrm{~h}$. (a) (i) Confirmation of SOD2 overexpression was determined by western blotting using $\beta$-actin as a loading control. (ii) ROS generation was determined as described in Materials and Methods section. (b) (i) The amount of autophagy (formation of AVOs and GFP-LC3 vacuoles (dots)) was determined following treatment with $\mathrm{H}_{2} \mathrm{O}_{2}$ and 2-ME. (ii) Expression of beclin-1 and conversion of LC3-I to LC3-II were determined by western blotting. $\beta$-Actin was western blotted as a loading control. (c) Cell death was determined as described above. Standard error represents three independent experiments. $P$-value represents significant difference between conditions where $P<0.05$

cells decreased ROS generation, autophagosomes and autophagic cell death.

In contrast to overexpressing SOD2, suppressing expression of SOD2 would theoretically increase ROS generation, autophagosomes and autophagic cell death. In HeLa cells, expression of SOD2 was successfully reduced by SOD2 siRNA (Figure 6a). As expected, the levels of $\mathrm{H}_{2} \mathrm{O}_{2}$ - and 2-ME-induced ROS generation, autophagosomes (formation of AVOs and GFP-LC3 vacuoles) and cell death were significantly increased by SOD2 siRNA (Figure $6 \mathrm{~b}-\mathrm{d}$ ). Addition of 3-MA reduced $\mathrm{H}_{2} \mathrm{O}_{2}$-induced cell death in cells with knock down SOD2 expression (Figure 6d). In contrast, the level of $\mathrm{H}_{2} \mathrm{O}_{2}$-induced apoptosis (formation of sub-G1 peaks) was not significantly affected by SOD2 siRNA (Figure 6e).

Since it was reported that the caspase inhibitor zVAD induced autophagy which then led to catalase degradation and ROS generation, ${ }^{15}$ we have investigated whether ROS generation was also a downstream effect of autophagy induced by oxidative stress $\left(\mathrm{H}_{2} \mathrm{O}_{2}\right.$ or 2-ME). When $\mathrm{H}_{2} \mathrm{O}_{2}$ induced autophagosome accumulation was inhibited by beclin-1, atg-5 and atg-7 siRNAs in HEK293 cells
(Figure 2c), $\mathrm{H}_{2} \mathrm{O}_{2}$-induced ROS generation was not affected (Figure 7). Similar results were found in U87 cells transfected with atg-7 siRNA (Supplementary Figure S4F) and in HeLa cells transfected with beclin-1 and atg-5 siRNA (data not shown). This indicates that $\mathrm{H}_{2} \mathrm{O}_{2}$ - and 2-ME-induced ROS generation occurs upstream of autophagy.

Autophagy fails to be induced by $\mathrm{H}_{2} \mathrm{O}_{2}$ and 2-ME in nontransformed mouse astrocytes. Since $\mathrm{H}_{2} \mathrm{O}_{2}$ and 2-ME can induce ROS generation that triggers autophagy and autophagic cell death in astrocyte-derived glioma cells (U87 cells), we investigated whether $\mathrm{H}_{2} \mathrm{O}_{2}$ and 2-ME can increase autophagosomes and autophagic cell death in primary mouse astrocytes. Primary mouse astrocytes were treated with increasing concentrations of $\mathrm{H}_{2} \mathrm{O}_{2}(0.1-3.0 \mathrm{mM})$ and 2-ME $(0.1 \mathrm{mM})$. This induced ROS generation (Figure $8 \mathrm{a}$ ) but at lower levels compared to HEK293 or U87 cells (Figure 4a and Supplementary Figure S6). Increasing concentration of $\mathrm{H}_{2} \mathrm{O}_{2}$ also failed to further increase ROS generation (Figure 8a). After $\mathrm{H}_{2} \mathrm{O}_{2}$ and 2-ME treatment, mouse primary astrocytes failed to significantly increase AVOs 


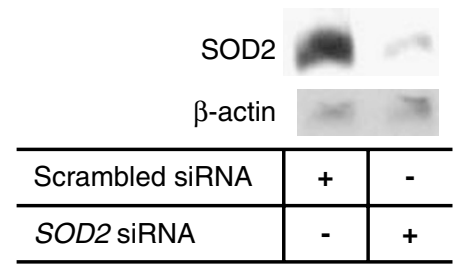

HeLa cells (wt)

b
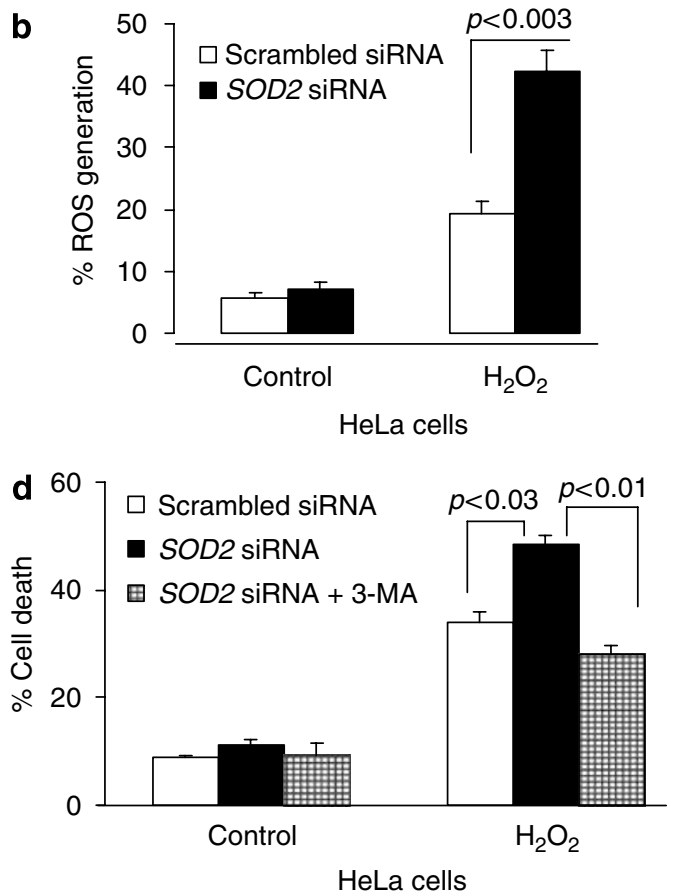

c
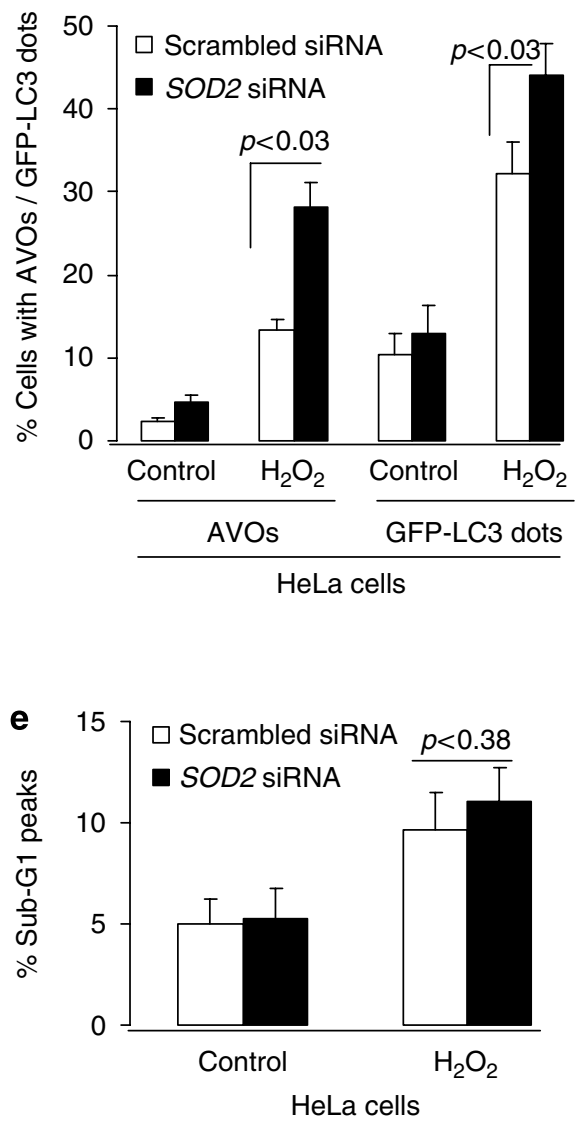

Figure 6 Silencing SOD2 expression by siRNA increases autophagic cell death induced by $\mathrm{H}_{2} \mathrm{O}_{2}$. (a) SOD2 expression was reduced by SOD2 siRNA in HeLa cells (wt) as determined by western blotting. $\beta$-Actin was western blotted as a loading control. Cells were treated with $\mathrm{H}_{2} \mathrm{O}_{2}(1.0 \mathrm{mM})$ for $24 \mathrm{~h}$ and then, (b) ROS generation, (c) autophagy (formation of AVOs and GFP-LC3 vacuoles (dots)), (d) cell death and (e) apoptosis (formation of sub-G1 peaks) were determined as stated in Materials and Methods section. Standard error represents three independent experiments. $P$-value represents significant difference between conditions where $P<0.05$

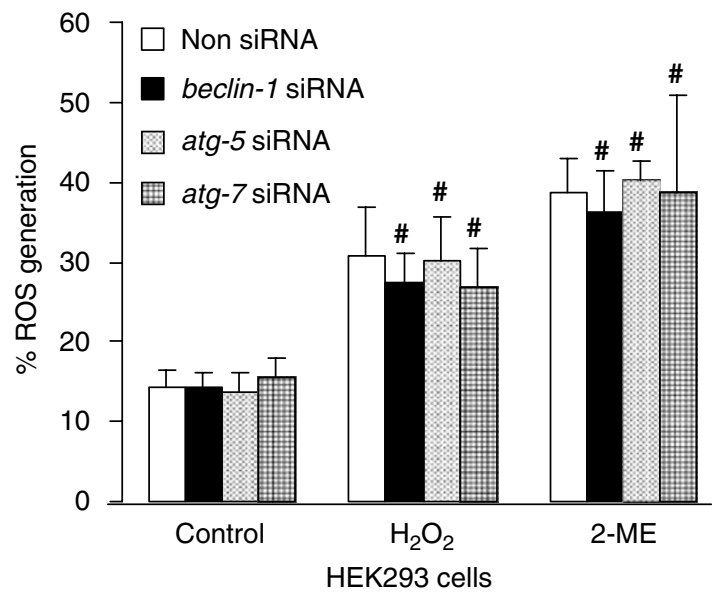

Figure 7 Inhibition of autophagy has no effect on ROS production induced by $\mathrm{H}_{2} \mathrm{O}_{2}$ and 2-ME. ROS generation was determined as described in Materials and Methods section after autophagy genes beclin-1, atg- 5 and atg- 7 were silenced by siRNAs and cells treated with $\mathrm{H}_{2} \mathrm{O}_{2}(1.0 \mathrm{mM})$ and 2-ME $(0.1 \mathrm{mM})$ for $48 \mathrm{~h}$ in $\mathrm{HEK} 293$ cells. \#Represents $P>0.05$ compared to 'Non siRNA' condition. Standard error represents three independent experiments formation, GFP-LC3 vacuoles formation, beclin-1 expression and conversion of LC3-I to LC3-II even in the presence of lysosomal inhibitor $\mathrm{NH}_{4} \mathrm{Cl}$ that prevents degradation of LC3- $\mathrm{II}^{24}$ in these cells (Figure 8b). Even at $3.0 \mathrm{mM} \mathrm{H}_{2} \mathrm{O}_{2}$ treatment, primary mouse astrocytes still failed to induce AVO formation (data not shown). This indicates that oxidative stress fails to induce autophagy in mouse primary astroyctes. However, $\mathrm{H}_{2} \mathrm{O}_{2}$ and 2-ME treatment induced apoptosis (Figure 8c) and cell death (Figure 8d) in these astrocytes. Under starvation conditions, primary mouse astroyctes were capable of inducing autophagy as determined by increased AVO formation and GFP-LC3 vacuole formation (Supplementary Figure S7) and by increased expression of LC3-II (Figure 8biv). To determine whether this difference between human transformed cell lines and mouse primary cells was not due to differences between human and mouse cells, the transformed mouse NIH 3T3 fibroblast cell line was treated with $\mathrm{H}_{2} \mathrm{O}_{2}$ and 2-ME. The amount of ROS generation, AVO formation and GFP-LC3 vacuoles formation increased and the amount of $\mathrm{H}_{2} \mathrm{O}_{2}$ - and 2-ME induced cell death was blocked by 3-MA (Supplementary Figure S8). Therefore, 


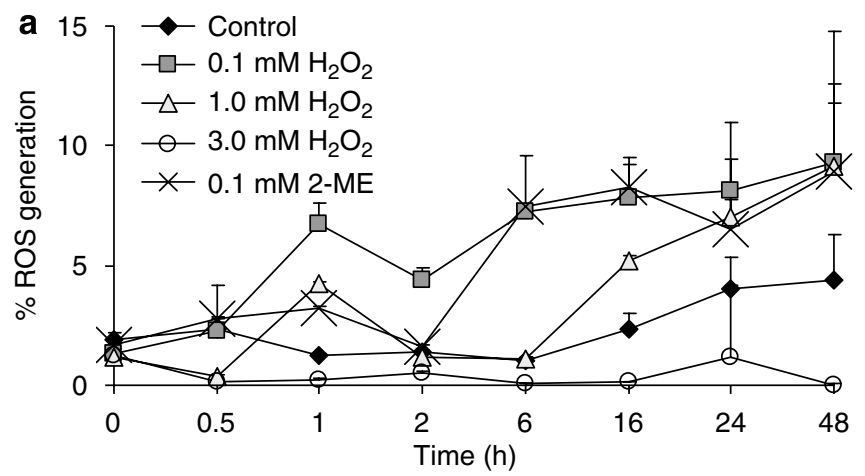

Mouse astrocytes

b

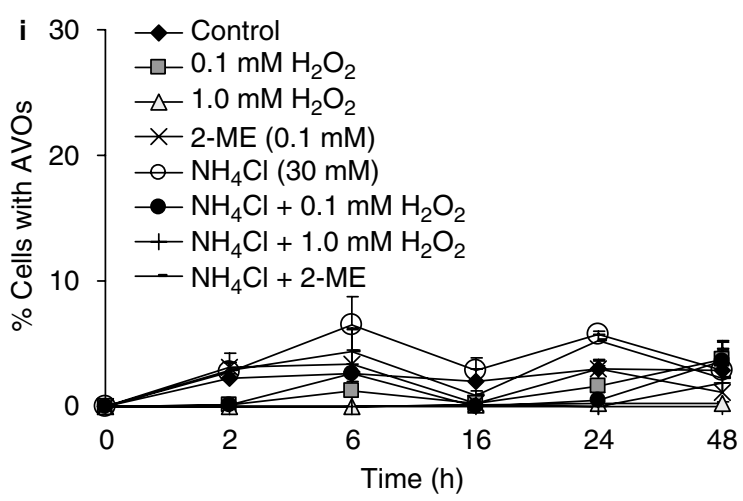

Mouse astrocytes

iii

Control $\mathrm{H}_{2} \mathrm{O}_{2}$ 2-ME

Beclin-1

$\beta$-Actin

Mouse astrocytes

iv
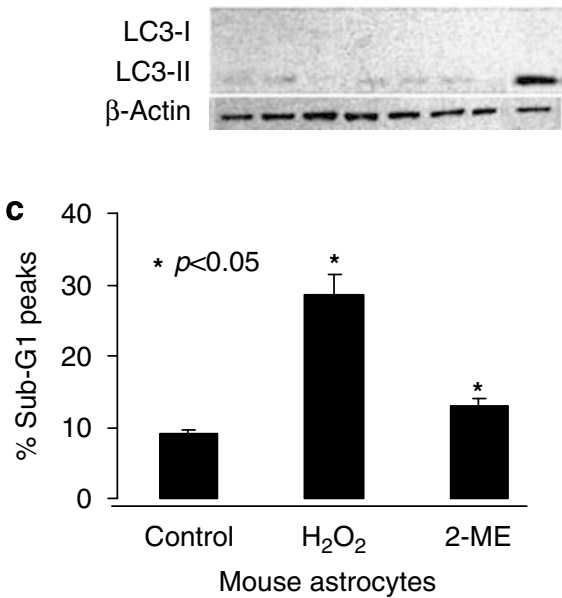

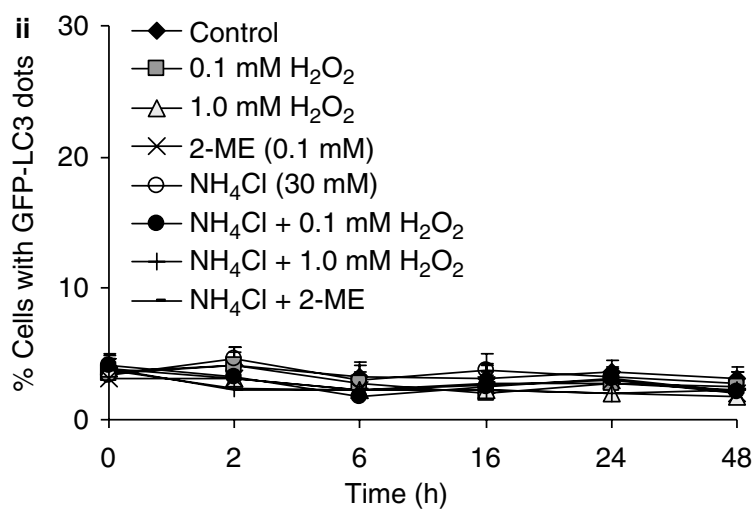

Mouse astrocytes

iv

\begin{tabular}{c|c|c|c|c|c|c|c|c}
\hline $\mathrm{H}_{2} \mathrm{O}_{2}$ & - & + & - & - & + & - & - & - \\
\hline $2-\mathrm{ME}$ & - & - & + & - & - & + & - & - \\
\hline $\mathrm{NH}_{4} \mathrm{Cl}$ & - & - & - & + & + & + & - & - \\
\hline Starvation & - & - & - & - & - & - & - & + \\
\hline Time (h) & \multicolumn{7}{|c}{24} \\
\hline \multicolumn{1}{c}{ Mouse astrocytes }
\end{tabular}

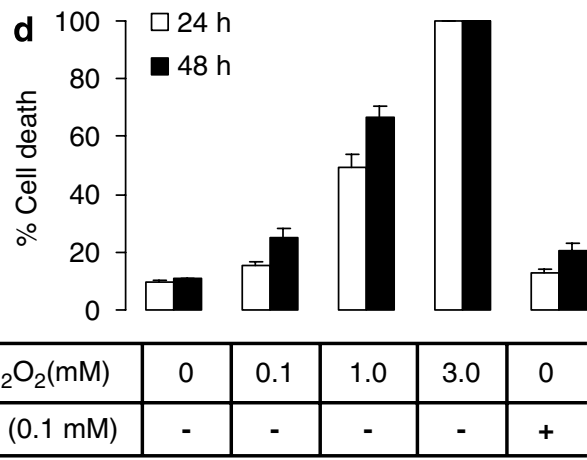

Mouse astrocytes

Figure $8 \quad \mathrm{H}_{2} \mathrm{O}_{2}$ and 2-ME fail to induce autophagy in primary mouse astrocytes. Primary mouse astrocytes were treated with $\mathrm{H}_{2} \mathrm{O}_{2}$ or 2-ME as indicated. (a) The amount of ROS generation was determined over a $48 \mathrm{~h}$ time course. (b) Autophagy was determined as described above. (i) AVOs formation over a 48-h time course in the absence and presence of the lysosomal inhibitor $\mathrm{NH}_{4} \mathrm{Cl}(30 \mathrm{mM})$. (ii) Formation of GFP-LC3 vacuoles (dots) over a 48 -h time course in the absence and presence of $\mathrm{NH}_{4} \mathrm{Cl}$. (iii) $\mathrm{Beclin}-1$ expression was determined by western blotting after cells were treated with $\mathrm{H}_{2} \mathrm{O}_{2}(1.0 \mathrm{mM})$ or 2-ME $(0.1 \mathrm{mM})$ for $6 \mathrm{~h}$. $\beta$-Actin was western blotted as a loading control. (iv) Conversion of LC3-I to LC3-II was determined by western blotting after cells were treated with $\mathrm{H}_{2} \mathrm{O}_{2}$ or 2-ME for $24 \mathrm{~h}$ in the absence and presence of $\mathrm{NH}_{4} \mathrm{Cl}$. Starvation of glucose and pyruvate for $72 \mathrm{~h}$ was used as a control. $\beta$-Actin was western blotted as a loading control. (c) Apoptosis (formation of sub-G1 peaks) was determined as described in Materials and Methods section after cells were treated with $\mathrm{H}_{2} \mathrm{O}_{2}$ and 2-ME for $48 \mathrm{~h}$. (d) Cell death was determined as previously indicated. When included, $\mathrm{NH}_{4} \mathrm{Cl}$ was preincubated with cells for $1 \mathrm{~h}$ before the addition of $\mathrm{H}_{2} \mathrm{O}_{2}$ or 2-ME. Standard error represents three independent experiments. *Represents $P<0.05$ compared to control condition 
unlike in transformed cells, $\mathrm{H}_{2} \mathrm{O}_{2}$ and 2-ME preferentially induced apoptotic cell death in nontransformed primary mouse astrocytes.

\section{Discussion}

Oxidative stress has been shown to induce autophagy under certain conditions such as ischemia and reperfusion. ${ }^{12}$ The ability of oxidative stress to induce autophagic cell death was unknown. Herein we demonstrated for the first time that using $\mathrm{H}_{2} \mathrm{O}_{2}$ and 2-ME to induce oxidative stress caused autophagyinduced cell death in transformed cell line HEK293 and cancer cell lines U87 and HeLa cells. Blocking autophagosome accumulation through chemical inhibitors or knocking down autophagy genes effectively blocked oxidative stress-induced cell death. Furthermore, blocking ROS generation also effectively blocked autophagy and cell death. In contrast, mouse primary astrocytes following oxidative stress failed to undergo autophagy. This indicates that oxidative stress induces autophagy-mediated cell death in transformed and cancer cells.

Autophagic cell death remains controversial since autophagy contributes to cell survival under stress such as starvation. ${ }^{4}$ In mice lacking autophagy, neural cell death is increased leading to neurological disorders. ${ }^{25}$ On the other hand, autophagic cell death was shown to be induced by a short mitochondrial form of the ARF tumor suppressor protein p19ARF in HEK293T cells mediated by changes in the mitochondrial membrane potential. ${ }^{8}$ In U87 cells, we have found that oxidative stress failed to significantly change membrane potential (Supplementary Figure S9). The metabolic toxin arsenic trioxide induced autophagic cell death mediated by upregulation of pro-cell death Bcl-2 family member BNIP3. ${ }^{7}$ The selective degradation of catalase can lead to autophagic cell death. ${ }^{15}$ The double-knock out of proapoptotic genes bax and bak in mice embryonic fibroblasts $^{26}$ and in cancer cells ${ }^{27}$ favors autophagic cell death pathway. We have determined that under oxidative stress, autophagy contributes to cell death. Taken together, autophagy could contribute to both cell survival and cell death.

Besides autophagy, oxidative stress has been shown to induce apoptotic signaling pathways leading to cell death. ${ }^{21,23}$ We have demonstrated that $\mathrm{H}_{2} \mathrm{O}_{2}$ and 2-ME could induce both apoptotic and autophagic cell death. This is similar to the effect of arsenic trioxide $\left(\mathrm{As}_{2} \mathrm{O}_{3}\right)$ on cell death in human T-lymphocytic leukemia and myelodysplastic syndrome (MDS) cell lines. ${ }^{28}$ Indeed, when the caspase-dependent apoptosis was inhibited by the caspase inhibitor zVAD, autophagosome accumulation and total cell death induced by $\mathrm{H}_{2} \mathrm{O}_{2}$ or 2-ME were not inhibited. This indicates that when $\mathrm{H}_{2} \mathrm{O}_{2}$-or 2-ME-induced apoptotic cell death pathway is blocked, cells preferentially die by the autophagic pathway. Conversely, blockage of autophagosome accumulation failed to significantly alter apoptosis. This suggest that apoptosis occurs independent of autophagy.

The amount of oxidative stress-induced cell death was not completely blocked by inhibiting either apoptosis or autophagy. This indicates that there is a third cell death pathway. This third type of cell death could be the necrotic cell death pathway. This form of cell death is passive and causes cellular contents to be released to the extracellular space and often causes inflammation. Reports have shown that when apoptotic or autophagic cell death was blocked, necrotic cell death was observed. ${ }^{29}$ Furthermore, oxidative stress has been shown to trigger a lysosomal-dependent necrotic cell death. ${ }^{30}$ Thus, it is reasonable to assume that cells under oxidative stress could undergo cell death through multiple pathways including necrosis. Nevertheless, our results indicate that autophagic cell death pathway plays an important role in oxidative stress-induced cell death.

Autophagy pathways have been extensively studied. ${ }^{1-5}$ Under nutrient starvation, ROS induced autophagy through the oxidation of a cysteine residue on Atg4 that is required to induce autophagy. ${ }^{13}$ However, the role of ROS in the induction of autophagic cell death is not clear. A recent report suggests that ROS could be involved in caspase-independent cell death in macrophage cells. ${ }^{11}$ We found that the ROS scavenger tiron could block autophagic cell death but failed to affect apoptosis even though ROS can induce apoptosis. Tiron treatment however failed to completely eliminate oxidative stress-induced ROS generation suggesting that higher levels of ROS or the types of ROS generated might be important in regulating autophagy independent of apoptosis. Indeed, ROS have many effects on cells including DNA damage, mitochondrial dysfunction, activation of signaling pathways and activation of transcription factors leading to upregulation of genes. ${ }^{17}$ We have demonstrated that ROS induced beclin-1 expression and beclin-1 is required for ROSinduced autophagy. This agrees with the report by Thorpe et al. ${ }^{31}$ that autophagy genes were upregulated in response to oxidative stress in yeast Saccharomyces cerevisiae. The mechanism for ROS-mediated upregulation of beclin-1 and the differences between ROS-induced apoptosis and autophagy will be the focus for further investigation.

Cancer cells produce higher levels of ROS than normal cells, and this contributes to cancer progression. ${ }^{14,17,18}$ Trachootham et al. ${ }^{16}$ reported that increasing ROS generation selectively sensitized oncogenically transformed cells to $\beta$-phenylethyl isothiocyanate-induced cell death indicating that increasing ROS generation in cancer cells could be a strategy for cancer therapy. 2-ME is a promising antitumor agent, which is in Phase I and Phase II clinical trials. ${ }^{32-34}$ It was initially reported to inhibit SOD2 and copper, zincsuperoxide dismutase (SOD1), thereby increasing ROS levels. ${ }^{35}$ However, this conclusion was challenged. Hagen et al. $^{36}$ reported that 2-ME can inhibit mitochondrial electron transport chain (mETC) complex I and induce ROS generation suggesting that the mitochondria plays a significant role in ROS-mediated cell death. Indeed, overexpression of mitochondrial SOD2 blocks ROS generation and autophagosome accumulation induced by 2-ME. A strategy to sensitize cancer cells to drug-induced apoptosis is to combine an ROSgenerating drug with the inhibition of mitochondrial respiration enhancing ROS production and cell death such as combining $\mathrm{As}_{2} \mathrm{O}_{3}$ with rotenone (an inhibitor of mETC complex I). ${ }^{37} \mathrm{We}$ found that oxidative stress induces autophagic cell death and the combination of $\mathrm{H}_{2} \mathrm{O}_{2}$ and rotenone further increased $\mathrm{ROS}$ generation, autophagosomes and cell death supporting a role of ROS production in autophagic-induced cell death (data not shown). In addition, autophagy failed to be significantly 
induced in primary astrocytes under oxidative stress. Thus, targeting ROS generation could selectively induce autophagic cell death in cancer cells.

In conclusion, oxidative stress induces autophagy and provides a novel mechanism for oxidative stress-induced cell death that is selective toward transformed and cancer cells. This may lead to new strategies to develop therapeutic drugs that will selectively target cancer cells to undergo autophagyinduced cell death independent of apoptosis.

\section{Materials and Methods}

Reagents. Acridine orange (AO), ethidium bromide (EB), trypan blue, 3-MA, $\mathrm{H}_{2} \mathrm{O}_{2}, 2-\mathrm{ME}$, tiron and DAPI (4',6-diamidino-2-phenylindole) were purchased from Sigma-Aldrich Canada (Oakville, ON, Canada). Benzyloxycarbonyl-Val-Ala-Asp (zVAD fmk, zVAD) was purchased from Calbiochem (Mississaga, Ontario) and dihydroethidium (HE) from Invitrogen (Burlington, Ontario). HE, 2-ME, ZVAD and DAPI were dissolved in dimethyl sulfoxide (DMSO). 3-MA and $\mathrm{H}_{2} \mathrm{O}_{2}$ were dissolved in double distilled water. $\mathrm{AO}, \mathrm{EB}$ and trypan blue were dissolved in $1 \times \mathrm{PBS}$. The final concentration of DMSO in media was less than $0.1 \%$ and it did not have any effect on the activities tested in this study (data of DMSO effect were not shown in this study). The concentrations of some reagents used in this study were: $\mathrm{H}_{2} \mathrm{O}_{2}$ $1.0 \mathrm{mM}$; 2-ME, 0.1 mM; 3-MA, 2.0 mM; tiron, $1.0 \mathrm{mM}$; ZVAD, 0.1 mM; HE, $3.2 \mu \mathrm{M}$ and DAPI, $3.0 \mu \mathrm{M}$.

Antibodies and siRNAs. Beclin-1 and ATG-5 primary antibodies and their secondary antibody donkey anti-goat HRP were purchased from Santa Cruz Biotechnology, Inc. (CA, USA). ATG-7 antibodies were purchased from PromoKine Inc. (Germany). SOD2 antibodies were purchased from StressGen Biotechnologies (Victoria, Canada). Rabbit anti-actin antibody was purchased from Sigma, rabbit anti-LC3 antibody from Abgent Inc. and their secondary antibody goat anti-rabbit $\lg \mathrm{G}(\mathrm{H}+\mathrm{L}) \mathrm{HRP}$ from Bio-Rad Laboratories. The siRNA specific for human beclin-1 was purchased from Dharmacon (Lafayette, $\mathrm{CO}$, USA) and the sequences used were same as those by Degenhardt et al. ${ }^{29}$ The siRNA specific for atg-5 was purchased from Sigma Proligo (The Woodlands, TX, USA) and the sequences used were same as those by Boya et al..$^{38}$ atg-7 siRNA was obtained from Ambion Inc. (TX, USA) targeting exons 1 and 2 and sod-2 siRNA was purchased from Ambion Inc.

Cell culture. Human embryonic kidney cell line HEK293, human glioma cancer cell line U87, human cervical cancer cell line HeLa and primary mouse astrocytes were maintained in a humidified $5 \% \mathrm{CO}_{2}, 37^{\circ} \mathrm{C}$ incubator in Dulbecco's modified Eagle's medium (DMEM) supplemented with $100 \mathrm{U} / \mathrm{ml}$ penicillin, $100 \mu \mathrm{g} / \mathrm{m}$ streptomycin (Invitrogen). Media used for HEK293 and HeLa were supplemented with 10\% bovine calf serum (BCS) and 10\% fetal bovine serum (FBS) (Invitrogen), respectively. Medium for the stabilized HeLa cells with overexpression of SOD2 was also supplemented with $0.2 \mathrm{mg} / \mathrm{ml}$ G418 (Life Technologies, Inc.). Medium for U87 was supplemented with $10 \% \mathrm{FBS}, 1 \mathrm{mM}$ sodium pyruvate and $2 \mathrm{mM}$ glutamine without penicillin and streptomycin. Medium for mouse astrocytes was supplemented with $10 \%$ FBS and $1.6 \%$ glucose. In this study, except otherwise stated, HeLa cells refer to the wild-type cell line.

Analysis of cell death. Cell death was analyzed by measuring the permeability of the plasma membrane to AO-EB or trypan blue. Cell suspension was centrifuged in an eppendorf tube. Supernatant was removed and cell pellet was resuspended in 100-300 $\mu \mathrm{l}$ PBS. Cells were stained with $5 \mu \mathrm{l}$ cocktail of AO $(100 \mu \mathrm{g} / \mathrm{ml})$ and EB $(100 \mu \mathrm{g} / \mathrm{ml})$ in PBS and $10 \mu \mathrm{l}$ suspension was applied onto a microscope slide, covered with a cover slide and cells were viewed under a fluorescent microscope. Live cells are permeable to AO but not to EB and stained green, and dead cells permeable to both $\mathrm{AO}$ and $\mathrm{EB}$, and $\mathrm{EB}$ stains the DNA red. This red staining is distinctive from $A O$ staining of autolysosomes (red) in the cytoplasm. At least 200 cells were counted for each treatment. Cell death can also be analyzed by staining cells with trypan blue and counting cells under a microscope. ${ }^{7}$ Since cell death can by analyzed by flow cytometry after cells were stained by $A O / E B$, it is possible to analyze cell death by flow cytometry after staining cells with trypan blue. Briefly, cells were collected and suspended in $0.2-0.5 \mathrm{ml}$ PBS in a FACS tube. Then, cells were stained with trypan blue with a final concentration of $0.04 \%$ for $5-10 \mathrm{~min}$ at room temperature. Stained cells were analyzed on a flow cytometer using CellQuest software (Becton Dickinson, San Jose, CA). The red filter $(675 \mathrm{~nm}, \mathrm{FL} 3-\mathrm{H})$ was used and histogram data on log scale were collected. Two peaks in the histograph were observed. The first peak represents viable cells, which were dimly fluorescent and not permeable to trypan blue. The second peak represents dead cells, which were brightly fluorescent and permeable to trypan blue. According to our experiments, the results from these two methods (AO/EB staincounting and trypan blue stain-flow cytometry) gave similar results in HEK293, U87 and HeLa cells. In this study, cell death was analyzed mainly by microscopic counting (AO/EB staining) and the results were confirmed at least once by flow cytometry (trypan blue staining).

Silencing beclin-1, atg-5, atg-7 or sod2 genes by siRNA. On the first day, same amount of cells were seeded in each Petri plate $(100 \times 20 \mathrm{~mm})$ and incubated at $37{ }^{\circ} \mathrm{C}$ and $5 \% \mathrm{CO}_{2}$. On the second day, cells (30-50\% confluency) were transfected with siRNA (scrambled, beclin-1 or atg-5 or atg-7 or SOD2). On the fourth day, cells from each big plate were split into six-well plates with same amount of cells in each well. On the fifth day, old media were removed, and fresh media and $\mathrm{H}_{2} \mathrm{O}_{2}$ were added. Cells in all plates were incubated at $37^{\circ} \mathrm{C}$ and $5 \% \mathrm{CO}_{2}$. On the sixth or seventh day, cells were collected and analyzed, and partial cells were lysed to make protein lysates for western blot. Transfection of siRNA into cells follows the Invitrogen protocols with some modifications. For transfection, in each Petri plate, $10 \mu \mathrm{l}$ of Oligofectamine ${ }^{\mathrm{TM}}$ Reagent (Invitrogen) was diluted with $40 \mu \mathrm{l}$ of plain DMEM medium (without serum) in an eppendorf tube and the diluted reagent was incubated at room temperature for $5-10 \mathrm{~min}$. In another eppendorf tube, $10 \mu \mathrm{l}$ of $20 \mu \mathrm{M}$ siRNA was added into $440 \mu \mathrm{l}$ of plain DMEM medium. Then, diluted Oligofectamine $^{\mathrm{TM}}$ Reagent was added to diluted siRNA solution, mixed gently, and incubated at room temperature for 15-20 min. The cells were washed once with plain DMEM medium. Then, $2 \mathrm{ml}$ plain DMEM medium and $500 \mu \mathrm{l}$ of the siRNAOligofectamine ${ }^{\mathrm{TM}}$ Reagent complex was added into each plate containing cells and mixed. For the 'Non siRNA plate', $2.5 \mathrm{ml}$ plain DMEM medium was added without Oligofectamine ${ }^{\mathrm{TM}}$ Reagent and siRNA. The cells were incubated for $4 \mathrm{~h}$ at $37^{\circ} \mathrm{C}$ and $5 \% \mathrm{CO}_{2}$. Then, $2.5 \mathrm{ml}$ plain DMEM and $400 \mu \mathrm{l}$ serum (FBS or BCS) was added into each plate, mixed and incubated at $37^{\circ} \mathrm{C}$ and $5 \% \mathrm{CO}_{2}$. The final concentration of siRNA in media was $40 \mathrm{nM}$.

Flow cytometric quantification of AVOs. Autophagy is characterized by the formation of AVOs (autophagosomes and autolysosomes). ${ }^{1}$ AVOs were quantified by flow cytometry after cells were stained by $\mathrm{AO}{ }^{7} \mathrm{AO}$ is a fluorescent weak base that accumulates in acidic spaces and fluoresces bright red (punctate staining (dots) in the cytoplasm, whereas AO/EB stains DNA in the nucleus and is detected by fluorescent microscopy). The intensity of the red fluorescence is proportional to the degree of acidity. Thus, the formation of AVOs can be quantified. Cell pellet was collected in an eppendorf tube and resuspended in $1 \mathrm{ml} \mathrm{PBS}$. The cell suspension was stained with $\mathrm{AO}(100 \mu \mathrm{g} / \mathrm{ml})$ for $15-20 \mathrm{~min}$. Cells were washed twice with PBS, resuspended in $0.3 \mathrm{ml} \mathrm{PBS}$ and analyzed on a flow cytometer using CellQuest software.

Staining autophagosomes with GFP-LC3. Cells were transfected with $1 \mu \mathrm{g}$ of GFP or GFP-LC3 expressing plasmid in each well of six-well plates using liptofectamine as per the manufacturer's instructions (Invitrogen). After $4 \mathrm{~h}$, cells were treated with $\mathrm{H}_{2} \mathrm{O}_{2}$ or 2-ME, the fluorescence of GFP or GFP-LC3 was viewed and the rate of GFP-LC3 vacuoles (autophagosomes) was counted under a fluorescent microscope. The DNA was stained with antifade DAPI solution after cells were fixed with $3.7 \%$ paraformaldehyde. When 3-MA or ZVAD was used in the combination with $\mathrm{H}_{2} \mathrm{O}_{2}$ or 2-ME in the treatment, it was preincubated in an incubator $\left(37^{\circ} \mathrm{C}, 5 \% \mathrm{CO}_{2}\right)$ for $1 \mathrm{~h}$

Flow cytometric analysis of apoptosis. Apoptosis was analyzed by measuring sub-G1 peaks (indication of DNA fragmentation) on a flow cytometer after cells were fixed with ethanol and stained with propidium iodide as stated previously. TUNEL assay (Roche Inc.) that detects DNA breaks was detected on flow cytometer as per the manufacturer's instructions.

Flow cytometric analysis of ROS. ROS generation was determined by flow cytometry after cells were stained with HE. HE is oxidized by ROS into EB (emission at $605 \mathrm{~nm}$ ) and fluoresces red. First, HE was dissolved in DMSO to make aliquots of stock solution of $1.6 \mathrm{mM}$ and kept at $-80^{\circ} \mathrm{C}$ in dark. When used $\mathrm{HE}$ is taken out, covered with aluminum foil, and kept on ice until it is melt. For staining of cells, cells were centrifuged down and the pellet was resuspended in $0.5 \mathrm{ml}$ PBS in 
an eppendorf tube. HE with a volume of $1 \mu \mathrm{l}$ and a final concentration of $3.2 \mu \mathrm{M}$ was added into the cell suspension and gently mixed. The mixture was incubated in dark in a water bath at $37^{\circ} \mathrm{C}$ for $15 \mathrm{~min}$. Then, the cell suspension was transferred into a $5 \mathrm{ml}$ FALCON ${ }^{\circledR}$ FACS tube and analyzed on a flow cytometer using CellQuest software within $10 \mathrm{~min}$

Electron microscopy. Cells were collected and fixed in $2 \%$ paraformaldehyde, $0.1 \%$. glutaraldehyde in $0.1 \mathrm{M}$ sodium cacodylate for $2 \mathrm{~h}$, postfixed with $1 \% \mathrm{OsO}_{4}$ for $1.5 \mathrm{~h}$, washed and finally stained for $1 \mathrm{~h}$ in $3 \%$ aqueous uranyl acetate. The samples were then washed again, dehydrated with graded alcohol, and embedded in Epon-Araldite resin (Canemco Inc.). Ultrathin sections were cut on a Reichert ultramicrotome, counterstained with $0.3 \%$ lead citrate and examined on a Philips EM420 electron microscope.

Western blot analysis. Western blot analysis was performed as stated previously. ${ }^{39}$ Tris-glycine SDS-PAGE was used, except for the detection of conversion of LC3-I (18 kDa, cytoplasmic form) to CL3-II $(16 \mathrm{kDa}$, preautophagosomal and autophagosomal membrane-bound form), where TrisTricine SDS-PAGE was used.

Statistical analysis. All experiments were repeated at least three times and each experiment was carried out at least by triplicates. The data were expressed as means \pm S.E. (standard error) $(n \geqslant 3)$. Statistical analysis was performed by using Student's $t$ test using at least three independent data points. The criterion for statistical significance was $P<0.05$. The software used is excel or sigma blot.

Acknowledgements. This work was supported from a grant from the Canadian Institutes for Health Research. YC is supported by a post-doctoral fellowship from CancerCare Manitoba Foundation. SBG is supported by a New Investigator Award from the Canadian Institutes for Health Research. We thank Dr. Ludger Klewes for technical support in using the flow cytometer. In addition, special thanks to Elizabeth Henson, Meghan Azad, Xiaojie Hu and WenYan Liu for technical assistance.

1. Levine B, Yuan J. Autophagy in cell death: an innocent convict? J Clin Invest 2005; 115 2679-2688.

2. Gozuacik D, Kimchi A. Autophagy as a cell death and tumor suppressor mechanism. Oncogene 2004; 23: 2891-2906.

3. Mariño G, López-Otín C. Autophagy: molecular mechanisms, physiological functions and relevance in human pathology. CMLS Cell Mol Life Sci 2004; 61: 1439-1454.

4. Codogno $P$, Meijer AJ. Autophagy and signaling: their role in cell survival and cell death. Cell Death Differ 2005; 12: 1509-1518.

5. Baehrecke EH. Autophagy: dual roles in life and death? Nat Rev Mol Cell Biol 2005; 6 : 505-510.

6. Kanzawa $\mathrm{T}$, Kondo $\mathrm{Y}$, Ito $\mathrm{H}$, Kondo $\mathrm{S}$, Germano I. Induction of autophagic cell death in malignant glioma cells by arsenic trioxide. Cancer Res 2003; 63: 2103-2108.

7. Kanzawa T, Zhang L, Xiao L, Germano IM, Kondo Y, Kondo S. Arsenic trioxide induces autophagic cell death in malignant glioma cells by upregulation of mitochondrial cell death protein BNIP3. Oncogene 2005; 24: 980-991.

8. Reef S, Zalckvar E, Shifman O, Bialik S, Sabanay H, Oren M et al. A short mitochondrial form of p19ARF induces autophagy and caspase-independent cell death. Mol Cell 2006; 22: 463-475.

9. Ito $\mathrm{H}$, Aoki H, Kuhnel F, Kondo $\mathrm{Y}$, Kubicka $\mathrm{S}$, Wirth $\mathrm{T}$ et al. Autophagic cell death of malignant glioma cells induced by a conditionally replicating adenovirus. J Natl Cancer Inst 2006; 98: 625-636.

10. Xue L, Fletcher GC, Tolkovsky AM. Mitochondria are selectively eliminated from eukaryotic cells after blockade of caspases during apoptosis. Curr Biol 2001; 11: 361-365.

11. Xu Y, Kim SO, Li Y, Han J. Autophagy contributes to caspase-independent macrophage cell death. J Biol Chem 2006; 281: 19179-19187.

12. Matsui $Y$, Takagi H, Qu X, Adbellatif M, Sakoda $H$, Asano $T$ et al. Distinct roles of autophagy in the heart during ischemia and reperfusion: roles of AMP-activated protein kinase and Beclin 1 in mediating autophagy. Circ Res 2007; 100: 914-922.

13. Scherz-Shouval R, Shvets E, Fass E, Shorer H, Gil L, Elazar Z. Reactive oxygen species are essential for autophagy and specifically regulate the activity of Atg4. EMBO J 2007; 26 : 1749-1760.
14. Pelicano H, Carney D, Huang P. ROS stress in cancer cells and therapeutic implications. Drug Resist Update 2004; 7: 97-110.

15. Yu L, Wan F, Dutta S, Welsh S, Liu Z, Freundt E et al. Autophagic programmed cell death by selective catalase degradation. Proc Natl Acad Sci USA 2006; 103: 4952-4957.

16. Trachootham D, Zhou Y, Zhang H, Demizu Y, Chen Z, Pelicano $\mathrm{H}$ et al. Selective killing of oncogenically transformed cells through a ROS-mediated mechanism by beta-phenylethy isothiocyanate. Cancer Cell 2006; 10: 241-252.

17. Schumacker PT. Reactive oxygen species in cancer cells: live by the sword, die by the sword. Cancer Cell 2006; 10: 175-176.

18. Waris $G$, Ahsan $H$. Reactive oxygen species: role in the development of cancer and various chronic conditions. J Carcinog 2006; 5: 14

19. Benassi B, Fanciulli M, Fiorentino F, Porrello A, Chiorino G, Loda M et al. c-Myc phosphorylation is required for cellular response to oxidative stress. Mol Cell 2006; 21 509-519.

20. Gao N, Rahmani M, Dent P, Grant S. 2-Methoxyestradiol-induced apoptosis in human leukemia cells proceeds through a reactive oxygen species and Akt-dependent process. Oncogene 2005; 24: 3797-3809

21. Takeda M, Shirato I, Kobayashi M, Endou H. Hydrogen peroxide induces necrosis, apoptosis, oncosis and apoptotic oncosis of mouse terminal proximal straight tubule cells. Nephron 1999; 81: 234-238.

22. Li L, Heldin NE, Grawe J, Ulmsten U, Fu X. Induction of apoptosis or necrosis in human endometrial carcinoma cells by 2-methoxyestradiol. Anticancer Res 2004: 24: 3983-3990.

23. Fleury C, Mignotte B, Vayssiere JL. Mitochondrial reactive oxygen species in cell death signaling. Biochimie 2002; 84: 131-141.

24. Mizushima N, Yoshimori T. How to interpret LC3 immunoblotting? Autophagy 2007; 3 e-pub ahead of print.

25. Hara T, Nakamura K, Matsui M, Yamamoto A, Nakahara Y, Suzuki-Migishima $R$ et al. Suppression of basal autophagy in neural cells causes neurodegenerative disease in mice. Nature 2006; 441: 885-889.

26. Shimizu S, Kanaseki T, Mizushima N, Mizuta T, Arakawa-Kobayashi S, Thompson CB et al. Role of $\mathrm{Bcl}-2$ family proteins in a non-apoptotic programmed cell death dependent on autophagy genes. Nat Cell Biol 2004; 6: 1221-1228.

27. Buytaert E, Callewaert G, Vandenheede JR, Agostinis P. Deficiency in apoptotic effectors Bax and Bak reveals an autophagic cell death pathway initiated by photodamage to the endoplasmic reticulum. Autophagy 2006; 2: 238-240.

28. Qian W, Liu J, Jin J, Ni W, Xu W. Arsenic trioxide induces not only apoptosis but also autophagic cell death in leukemia cell lines via up-regulation of Beclin-1. Leuk Res 2007; 31: $329-339$

29. Degenhardt K, Mathew R, Beaudoin B, Bray K, Anderson D, Chen G et al. Autophagy promotes tumor cell survival and restricts necrosis, inflammation, and tumorigenesis. Cancer Cell 2006; 10: 51-64.

30. Brunk UT, Dalen H, Roberg K, Hellquist HB. Photo-oxidative disruption of lysosomal membranes causes apoptosis of cultured human fibroblasts. Free Radic Biol Med 1997; 23: $616-626$

31. Thorpe GW, Fong CS, Alic N, Higgins VJ, Dawes IW. Cells have distinct mechanisms to maintain protection against different reactive oxygen species: oxidative-stress-response genes. Proc Natl Acad Sci USA 2004; 101: 6564-6569.

32. Mooberry SL. New insights into 2-methoxyestradiol, a promising antiangiogenic and antitumor agent. Curr Opin Oncol 2003; 15: 425-430.

33. Mooberry SL. Mechanism of action of 2-methoxyestradiol: new developments. Drug Resist Update 2003; 6: 355-361.

34. Pribluda VS, Gubish Jr ER, Lavallee TM, Treston A, Swartz GM, Green SJ. 2Methoxyestradiol: an endogenous antiangiogenic and antiproliferative drug candidate. Cancer Metast Rev 2000; 19: 173-179.

35. Huang P, Feng L, Oldham EA, Keating MJ, Plunkett W. Superoxide dismutase as a target for the selective killing of cancer cells. Nature 2000; 407: 390-395.

36. Hagen T, D'Amico G, Quintero M, Palacios-Callender M, Hollis V, Lam F et al. Inhibition of mitochondrial respiration by the anticancer agent 2-methoxyestradiol. Biochem Biophys Res Commun 2004; 322: 923-929.

37. Pelicano H, Feng L, Zhou Y, Carew JS, Hileman EO, Plunkett $W$ et al. Inhibition of mitochondrial respiration: a novel strategy to enhance drug-induced apoptosis in human leukemia cells by a reactive oxygen species-mediated mechanism. J Biol Chem 2003; 278 37832-37839.

38. Boya P, Gonzalez-Polo RA, Casares N, Perfettini JL, Dessen P, Larochette N et al Inhibition of macroautophagy triggers apoptosis. Mol Cell Biol 2005; 25 1025-1040.

39. Kabore AF, Sun J, Hu X, McCrea K, Johnston JB, Gibson SB. The TRAIL apoptotic pathway mediates proteasome inhibitor induced apoptosis in primary chronic lymphocytic leukemia cells. Apoptosis 2006; 11: 1175-1193. 